\author{
Andrei N. Medushevskiy \\ National Research University Higher School of Economics (HSE University), \\ Russian Federation
}

ORCID: 0000-0002-4314-662X

amedushevsky@mail.ru

\title{
Global Constitutionalism and Legal Fragmentation: The Populist Backslide in Central and Eastern Europe*
}

\author{
Konstytucjonalizm globalny a fragmentacja prawa. Powrót \\ populizmu w Europie Środkowej i Wschodniej
}

\begin{abstract}
Globalisation has provoked a deep transformation in international law, political affairs and governance with contradictory consequences. It has stimulated the cosmopolitan project of global constitutionalism, transnational integration and the unification of democratic standards. However, it also resulted in the fragmentation of international affairs, the deterioration of constitutional democracy and a feeling of a growing shortage in democracy on national and international levels of governance. Trying to balance the impact of these two opposing trends, the author analyses the positive and negative effects of globalisation on constitutional development regarding such issues as transnational constitutionalisation, democracy and national sovereignty, the changing place of multilayer constitutionalism, the international separation of powers, and the system of global governance in the establishment of transnational constitutional democratic legitimacy. From this point of view, the populist backslide in Central and Eastern Europe (CEE) looks dangerous and unforeseen, but it is a systemic and potentially predictable reaction of global regions on the uneven character of integration, the lack of democratic legitimacy and a new answer to the contortions and dysfunctions of global governance. An adequate response to these challenges could be found in a new concept of constitutional integration based on ongoing dialogue between the transnational and national actors
\end{abstract}

CORRESPONDENCE ADDRESS: Andrey N. Medushevskiy, PhD, Doctor of Sciences (Philosophy), Tenured Professor at the National Research University Higher School of Economics (HSE University), Faculty of Social Sciences, 20, Myasnitskaya st., Moscow, 101000, Russian Federation.

* The publication was prepared within the framework of the Academic Fund Program at the National Research University Higher School of Economics (HSE University) in 2020-2021 (grant no. 20-01-006). 
of legal globalisation. This dialogue is possible by using a conflict-mediation strategy, elaborated by international experts, especially, for the deliberation of complex and protracted conflicts, which have no clear practical solutions in the short to medium term.

Keywords: global constitutionalism; constitutionalisation; fragmentation; sovereignty; legitimacy; conflict-mediation strategy

\section{INTRODUCTION}

The international debate on global legal stability therefore cannot ignore the problem of constitutional transformation - legal integration vs. fragmentation dispute. The most simple solution to the dilemma consists in the polarised opposition of two trends in the development of the international legal order, namely, integration (in the form of the constitutionalisation of international law) and its fragmentation (in form of the separation of different global constitutional regions, supra-national actors or regimes). According to this view, the two rival trends cannot be coordinated and a sharp collision cannot be avoided. The result could be described as a "zero-sum game", as progress in integration means an equal regress in fragmentation and vice versa. This approach is therefore useful as a methodological presumption grounded on the very abstract, linear and teleological vision of globalisation considering its development from a black and white perspective and associating it strictly with positive results - progress in human rights protection, the supremacy of law and law-based states. The current global pandemic, however, reveals the other side of globalisation - economic recession, legal contradictions, the prevalence of egoistic motives, and the perceived interests of separate regions and national states over general international values or a different interpretation of its content and "common" character. That simple fact makes it important to reconsider the complex character of legal globalisation and the reciprocal relations between its opposite sides - constitutionalisation and the fragmentation of international constitutionalism.

Among the priorities of the academic community since the end of the Cold War in 1990 are global integration, transnational law and European constitutionalism. The key effort has concentrated on the analysis of the constitutional transformation in all countries - primarily members of the Council of Europe - by monitoring the positive and negative results. The criteria for this evaluation were founded on "global", "Western" or European legal values and standards and the accumulated experience of the transnational accommodation of constitutional principles in different political and cultural traditions. This system of criteria, elaborated by international experts, oriented policy makers toward integration - the creation of the European Union as a principally new legal entity and, perhaps, a model for future global constitutional settlement. That strategy presumed the development of conventional 
liberal democracy by providing legal recommendations and promoting international constitutional reform for all governments which confronted such difficulties but who demonstrated the readiness to establish and protect democracy, the rule of law, the separation of powers, an independent judiciary, and the protection of human rights. This was based on the belief in the future triumph of Western or European liberal values, in spite of all the current conflicts, difficulties and misperceptions of constitutional transformation, which could and should be overcome by the "natural" self-evidence of the competitive preeminence of the liberal model. This vision of the future, attached to a solid ideological legitimacy, played a twofold role in the projection of global constitutionalism, making it a practical tool for international integration but also an ideological illusion.

By doing this important work, the European academic community, over the past 30 years, has achieved sufficient results in the area of global and comparative studies, practical reforms and teaching activities in different countries and has confronted similar challengers to democratic transition and constitutional modernisation. Current developments in global and European constitutionalism have shown grounds for optimism but also a preoccupation with the changing place and role of liberal legal values, regarding issues such as the growing populism, nationalism, constitutional backsliding, counter-reforms, and even the rejection of previously accepted democratic institutions and legal guarantees by some governments. This trend makes it important to concentrate on this negative turn in order to understand its causes, implications and possible outcomes for the future of global legal system.

This article analyses the principal aspects of the problem: the general impact of globalisation on legal development; legal integration and fragmentation as two opposing but mutually compatible processes in international affairs; the balance of optimistic and pessimistic interpretations of global constitutionalism; new challenges to democracy and the nature of the current constitutional backslash. We articulate the logic of its origins and historical evolution in Central and Eastern Europe (CEE); the erosion of the quest for legitimacy in new political regimes; the comparative place and peculiarities of the post-Soviet region; the impact of the Russian "revisionist" constitutional model; and the changing place of constitutional jurisprudence in the countries under consideration.

In the concluding parts of the work, the author discusses the possibility of a new conflict-mediation strategy as a methodological tool for resolving the contradiction between the participants - transnational and national actors of legal globalisation. Considering the growing fragmentation in international relations as a real threat to global legal stability and a way toward "normative disorder", this paper proposes a pragmatic and value-free evaluation of this trend putting forward some recommendations to overcome this negative dynamic. From this point of view, global constitutionalism is not a definitive solution but a new framework for international dialogue about the future of the international legal order. 


\section{GLOBALISATION: COSMOPOLITAN, INTERNATIONAL AND NATIONAL CONSTITUTIONAL REGULATION}

The theory of cosmopolitan or global constitutionalism presupposes the possibility of a new synthesis of international and constitutional law in a new legal settlement - global, transnational or supra-national law. ${ }^{1}$ The theory of global constitutionalism has several important presumptions, including that the description of legal globalisation is possible in terms of classic constitutionalism; that the categories of global, transnational and national constitutionalism are appropriate to reflect the nature and hierarchy of the different levels of the international legal regulation; and that the normative substance of global governance could be subsequently extracted from the "constitutionalisation" of the international law. ${ }^{2}$ Thus, the essence of constitutionalisation is the convergence of international and national legal norms - the progressive influence of international treatises on domestic constitutionalism, and the international adoption and incorporation of some elements of traditional domestic constitutional law, first of all, guarantees of basic human rights and freedoms. ${ }^{3}$ These assumptions, if admitted, make the whole picture clearer but include some unavoidable simplifications regarding the complexity of the legal sources of global law, which includes the norms of international law and custom, and a different set of norms and principles of national constitutions, which would be difficult to unify without enforced standardisation.

The conflict-provoking potential of current legal regulation originates from three conflicting and differently oriented trends, rooted in the construction of modern European constitutional design: the cosmopolitan vision of global constitutionalism; transnational constitutionalism; and the idea of national constitutionalism and jurisprudence.

(1) Global constitutionalism, rooted deeply in European history, means theory and practice is oriented toward the cosmopolitan establishment of a new international order based on the values and norms which are common (or would be common) to the whole of humankind. ${ }^{4}$ In spite of different and contradictory interpretations of this concept and ways to achieve this goal, the ideal of a global constitution played a very important role in the formative debates before and after the creation of the EU.

${ }^{1}$ Handbook on Global Constitutionalism, eds. A.F. Lang, A. Wiener, Cambridge 2017; A. Atilgan, Global Constitutionalism: A Socio-Legal Perspective, Heidelberg 2018; A. Peters, Global Constitutionalism, [in:] Encyclopedia of Political Thought, ed. M. Gibbus, London 2015, pp. 1484-1487.

2 Transnational Constitutionalism: International and European Perspectives, ed. N. Tsagourias, Cambridge 2007; O. Diggelmann, T. Altwicker, Is There Something Like a Constitution of International Law? A Critical Analysis of the Debate on World Constitutionalism, "Zeitschrift für ausländisches öffentliches Recht und Völkerrecht" 2008, vol. 68, pp. 623-650.

3 J. Klabbers, A. Peters, G. Ulfstein, The Constitutionalisation of International Law, Oxford 2009.

${ }^{4}$ A. Somek, The Cosmopolitan Constitution, Oxford 2014. 
The romantic vision, anchored in a cosmopolitan Kantian ideal of a global government, is visible in the United States of Europe and represents itself in the declared or tacit presumption that the new European construction would potentially be the best model not only for Europe but also for other regions of the world. The criticism of this concept spread and even began to prevail in academic debates only after the failure of the European constitution project (2004-2005). ${ }^{5}$

(2) Transnational or international constitutionalism and jurisprudence looks toward a more realistic compromise between two opposing trends in the search for a middle way between cosmopolitan and national constructions of the European Commonwealth and as a more effective combination of international norms and national constitutional norms. This concept of "international constitutional law" highlights the role of international law in bridging the gap between a supranational constitution and national legitimacy, and creates a stable construction of the main legal values via the selection of common constitutional principles, their normative incorporation into international human rights treatises, and their interpretation by the European Court of Human Rights (ECHR) and national constitutional courts. ${ }^{6}$ European law, according to some interpretations, was the result of this original amalgam of international and national law, opening the way for a cross-country judicial reexamination and the transformation of the European legal landscape. ${ }^{7}$ The ultimate result of that compromise strategy was the Lisbon Treaty (2007) which functionally plays the role of the European Constitution. This holistic strategy remains disputed in the context of the current sharp division in the EU over the meaning of constitutional values and their legal interpretation in some countries of CEE.

(3) National constitutionalism remains the basis for the principle of state sovereignty, historically granted by the Westphalian international order, substantially transformed and limited under globalisation to become the subject of debate about its future role in international and constitutional law.

Among the most important topics in this debate are:

- the changing place of the sovereign state in a post-Westphalian world, ${ }^{8}$

- the importance of a cross-cultural and comparative understanding of phenomena from different regional perspectives, ${ }^{9}$

${ }^{5}$ Global Constitutionalism without Global Democracy?, eds. C. Corradetti, G. Sartor, "Working Paper LAW" 2016/21, https://cadmus.eui.eu/bitstream/handle/1814/44286/LAW_2016_21.pdf?sequence $=1$ [access: 20.08.2021].

${ }^{6}$ Th. Kleinlein, A. Peters, International Constitutional Law, Oxford 2017.

7 G. Halmai, Perspectives on Global Constitutionalism: The Use of Foreign and International Law, The Hague 2014.

${ }^{8}$ Global Constitutionalism and Its Challenges to Westphalian Constitutional Law, ed. M. Belov, London 2018.

${ }^{9}$ Global Constitutionalism from European and East Asian Perspectives, eds. T. Suami, M. Kumm, A. Peters, D. Vanoverbeke, Cambridge 2018. 
- the perceived misbalance, if not eclipse, of the classic constitutional model in its traditional Western understanding, and the possibility of a new theory and political interpretation of constitutionalism, by its hypothetical disconnection from the principle of standard sovereignty, ${ }^{10}$

- the potential of the existing language of jurisprudence to reflect new diversified trends in legal development and reproduce semantically all the nuances of the crosscutting issues of legal regulation and global governance,

- the apparent difficulties and dubious character of the traditional juristic terminology elaborated and taken historically from only one global region (the West) for the interpretation of the legal reality of other regions and the cultural integrity of the entire world.

The idea of sovereign constitutionalism recently appeared to be a central point for the articulation of all anti-globalist, or "revisionist" movements in Europe and worldwide.

\section{INTEGRATION AND FRAGMENTATION: A SEPARATION OF WAYS IN GLOBAL LEGAL DEVELOPMENT}

Global constitutionalism is the theoretical construction and institutional reform agenda which tries to reflect the complex reality of integrating legal development based on the interaction and impact of international and national constitutional law. ${ }^{11}$ Global constitutionalism, at the current stage of the debate, combines three different perspectives which could potentially be more or less adequate to the new reality: new theory building, the ideology of social movements, and legal construction. ${ }^{12}$ The most visible representation of this phenomenon is in the progressive constitutionalisation of international law. ${ }^{13}$ This combines two options: the integration of constitutional norms into international treatises, and the reverse impact of these treatises on national law, their judicial system and practices (which becoming binding by international norms and judicial precedents). ${ }^{14}$ As theorists of global constitutionalism think, this process paves the way for the formation of the original type of transnational (supranational or global) constitutionalism. It could be

${ }^{10}$ The Twilight of Constitutionalism?, eds. P. Dobner, M. Louglin, Oxford 2010.

11 A. Atilgan, op. cit.; A. Peters, Global Constitutionalism ..., pp. 1484-1487.

12 A.N. Medushevskiy, Global Constitutionalism: The Theory of the Global Legal Order or a New Political Ideology?, "Historia Provinciae. The Journal of Regional History" 2020, vol. 4(3), pp. 995-1019.

13 Transnational Constitutionalism...

${ }^{14}$ J. Klabbers, A. Peters, G. Ulfstein, op. cit. 
represented as a pure legal phenomenon, in a form of "political constitutionalism"15 or in new concepts of global governance. ${ }^{16}$

The cosmopolitan constitutional ideal, in its holistic interpretation, ${ }^{17}$ provides an ambitious program of reconfiguring global governance, creating clear guidelines for the whole construction, for decision-making and a definition of its limits - globally, regionally and nationally. ${ }^{18}$ Cosmopolitan constitutionalism, in the contemporary understanding, originates in the international deliberations after the end of the First World War (the League of Nations) and after the Second World War. ${ }^{19}$ These represented the first projects of global constitutionalism (Chicago draft 1948) ${ }^{20}$ and formative debates on the UN Charter as the "Constitution of the International Community". "The cosmopolitan turn" in the legal and political agenda demonstrated the new importance of the foundation of the EU as a model of new political and legal organisation, described as global or integral constitutionalism, ${ }^{22}$ realising the Kantian ideal of a cosmopolitan international legal organisation in contemporary form. ${ }^{23}$ International law in Europe was a transformation and fixed a new reality "between tradition and renewal" in the form of the constitutionalisation of the transnational law of EU Member States. ${ }^{24}$

For optimists that new constellation is proof of the progressive enlargement of global constitutionalism in its Western liberal meaning: the development of transnational legal regulation, the limitation of the state sovereignty principle, and the creation of new international constitutional norms and actors beyond states, the implementation of the so-called "Trinitarian mantra of global constitutionalism". The Trinitarian mantra means the manifestation of the pure essence of Western thought: human rights, democracy and the rule of law. ${ }^{25}$ This group of experts believes that

${ }^{15}$ R. Bellamy, Political Constitutionalism: A Republican Defense of the Constitutionality of Democracy, Cambridge 2007.

${ }^{16}$ E. Benvenisti, Law of Global Governance, The Hague 2014.

17 D. Held, Cosmopolitanism: Ideas and Realities, Cambridge 2010.

18 Ruling the World? Constitutionalism, International Law, and Global Governance, eds. J.L. Dunoff, J.P. Trachtman, Cambridge 2009.

19 A. Mazover, No Enchanted Palace: The End of Empire and the Ideological Origins of the United Nations, Princeton-New Jersey 2009.

${ }^{20}$ Chicago draft (1948): Committee to Frame a World Constitution Preliminary Draft of a World Constitution, Chicago 1948.

${ }^{21}$ B. Fassbender, The United Nations Charter as the Constitution of the International Community, Leiden 2009.

${ }^{22}$ M. Kumm, The Cosmopolitan Turn in Constitutionalism: An Integrated Concept of Public Law, "Indiana Journal of Global Legal Studies" 2013, vol. 20(2), pp. 605-628.

23 J. Habermas, Zur Verfassung Europas, Berlin 2011; A. Somek, op. cit.

${ }^{24}$ M. Koskenniemi, International Law in Europe: Between Tradition and Renewal, "European Journal of International Law” 2005, no. 16, pp. 13-124.

${ }^{25}$ M. Kumm, A. Lang, J. Tully, A. Wiener, How Large Is the World of Global Constitutionalism?, "Global Constitutionalism" 2014, no. 3, pp. 1-8. 
global constitutionalism is a viable concept and its priorities are achievable through a simple transformation of its traditional meaning by "disconnecting Constitutions from Statehood", ${ }^{26}$ or by creating a new system of international judicial precedents and the mediation of transnational courts in cooperation with their national counterparts. ${ }^{27}$

For pessimists, it is proof of the growing uncertainty, if not crisis, of international law regarding such negative implications as the protection of the status quo and its unfairness, unification and formalisation. ${ }^{28}$ The entire concept of global constitutionalism for its opponents cannot be admitted because of its artificial theoretical character, one-dimensional (pro-liberal) ideological orientation and practical inconsistencies covering the degradation of representative democracy, the discrimination of minority rights and a general authoritarian teleological impetus. ${ }^{29}$ They look forward to creating an alternative concept of global constitutionalism based on ecology, the internet, post-liberal values and the protection of minorities instead of traditional, liberal, state-oriented solutions as represented in "A Manifesto for Feminist Global Constitutionalist Order". ${ }^{30}$

The optimist view of global legal integration recently became the object of sharp criticism by its opponents, who emphasized the role and growing importance of another process, the fragmentation of international law, which is regarded as an alternative concept of the global legal transformation. The fragmentation of international law reveals the, now obvious, trend for a disintegration in international relations. ${ }^{31}$ The disintegration of the global legal space in different global regions, states refusal to follow universal (or "internationally" adopted) principles of law, the growing commitment to find their own legal "identity" and attempts to reestablish a perceived "national sovereignty" ${ }^{32}$ This reestablishment of state sovereignty, presumably lost in process of "the global transition to democracy", very often implicates a form of populism - right-wing or left-wing - against the establishment, the ruling elites, liberal democratic principles or constitutional institutions. ${ }^{33}$

${ }^{26}$ U.K. Preuss, Disconnecting Constitutions from Statehood: Is Global Constitutionalism a Viable Concept?, [in:] The Twilight of Constitutionalism...

27 A.S. Sweet, A Cosmopolitan Legal Order: Constitutional Pluralism and Rights Adjudication in Europe, "Global Constitutionalism" 2012, vol. 1, pp. 53-90.

28 A. Atilgan, op. cit.; Global Constitutionalism and Its Challenges...

${ }^{29}$ Ch.E.J. Schwöbel, Global Constitutionalism in International Legal Perspective, Leiden-Boston 2011.

30 A. O'Donoghue, R.A. Houghton, A Manifesto for Feminist Global Constitutionalist Order, 2018, http://criticallegalthinking.com/2018/08/01/a-manifesto-for-feminist-global-constitutionalist-order [access: 15.08.2021]

${ }^{31}$ Fragmentation vs the Constitutionalisation of International Law: A Practical Inquiry, eds. A. Jakubowski, K. Wierczyńska, London 2016.

32 S. Bhandari, Global Constitutionalism and the Path of International Law, Leiden 2016.

33 A.N. Medushevskiy, Populism in the West and in Russia: A Comparative Perspective of Similarities and Differences, [in:] Populism as a Common Challenge, ed. C. Crawford, Berlin-Moscow 2017, pp. 47-57. 
In sharp contrast to the optimist vision of the global constitutional movement, contemporary critics emphasized important counter-arguments. First, by describing integration in terms of constitutionalisation, the globalists ignore the phenomenon of "false legitimacy" and the "illusive unification" of international legal norms, institutions and governance. Second, in reality, the integration has been significantly reduced by fragmentation. Third, the thesis about the end of the epoch of nation states seems to be an exaggeration and cannot explain the apparent growing role of the most powerful states in international affairs. Fourth, the assumption that international constitutionalisation would be the precursor to national democratisation appeared to be debatable or even wrong because many states demonstrated the opposite trend. Fifth, political practice cannot prove the positive transformation of international and constitutional law in terms of their mutual convergence. ${ }^{34} \mathrm{Ac}-$ cording to sceptics, international and national norms differ in their assumptions, normative logic and potential impact. Theoretically, a multilayer constitution is not a solution but a regress of traditional constitutional ideology represented in the classics of liberal thought - the destruction of the rule of law and representative parliament-like democracy by the unification of global ruling standards and henceforth favoring distortions and populist reactions. ${ }^{35}$

The cleft between integration and fragmentation means separate ways of global legal development, the formation of two different strategies in global constitutionalism. Legal globalisation at the crossroads symbolizes a choice between opposites for political elites. Are they mutually exclusive, compatible, or could they be combined into some new order in theory or in practice? The answer is possible through the reconstruction of key definitions and the political reality behind them.

\section{THE CLASH BETWEEN INTEGRATION AND FRAGMENTATION AS A CHALLENGE FOR THE GLOBAL LEGAL ORDER}

In the literature, in spite of its abundance, we cannot find any common interpretation of constitutionalisation. Different axiological and legal interpretations are represented by at least seven main concepts. First, for public international law, constitutionalisation means the search for legal control over politics inside the international legal order itself, in order to compensate for the erosion of this control in national states, by transferring to the international level those concepts which

${ }^{34}$ S. Xavier, False Universalism of Global Governance Theories: Global Constitutionalism, Global Administrative Law, International Criminal Institutions and the Global South, PhD Dissertation, 2015, http://digitalcommons.osgoode.yorku.ca/phd/20 [access: 15.08.2021].

${ }^{35}$ A. Sajó, R. Uitz, The Constitution of Freedom: An Introduction to Legal Constitutionalism, Oxford 2017. 
were traditionally reserved for national constitutions. ${ }^{36}$ Second, for the standard normative approach, this phenomenon is interpreted in "compensation theory" the mutual adaptation of different levels and institutions of global legal regulation and governance for the coordination and harmonisation of international processes. ${ }^{37}$ Third, from a sociological point of view, global constitutionalisation is not target oriented, and could be more the result of the self-installed societal regimes constituted, formed and selected by practice in a spontaneous rather than a purpose-oriented international legal strategy. ${ }^{38}$ Fourth, the institutionalist (or pluralist) approach focuses less on values, principles and norms and more on the whole entity of structures, institutes or actors which take part in the realisation of the power nexus beyond states. ${ }^{39}$ Fifth, for a constructivist approach in international relations, constitutionalisation means the process of identity changes and "normative self-entrapment" in which states and other international actors are involved. ${ }^{40}$ Sixth, for the functionalist approach, constitutionalisation is not necessarily a stable trend, and could go in different directions (unification, the limitation of democracy and legitimacy, the degradation of human rights) and its result determined, more or less, by a consciously admitted strategy, is adopted by society and elites. ${ }^{41}$ Seventh, the position of traditional constitutionalism argues for the possibility to transfer national constitutions to the transnational level and, if necessary, transform the meaning of traditional constitutionalism in order to reflect the perceived enfeeblement of the nation state or to make a new sense of this tradition for its adoption by international legal regulation. ${ }^{42}$

Fragmentation and its reciprocal relation to constitutionalisation pose many problems. We reconstructed five main approaches in this area:

1. As mentioned, there is a standard, generally shared, understanding of both processes as mutually incompatible: the progress of one automatically reduces the other.

2. Their treatment as cross-cutting issues: constitutionalisation (if not interpreted as a move to one global "super-constitution") itself is a fragmented

${ }^{36}$ E. De Wet, The Constitutionalisation of Public International Law, [in:] The Oxford Handbook of Comparative Constitutional Law, eds. M. Rosenfeld, A. Sajó, Oxford 2012.

37 A. Peters, Compensatory Constitutionalism: The Function and Potential of Fundamental International Norms and Structures, "Leiden Journal of International Law" 2006, vol. 19, pp. 579-610; A. Von Bogdandi, Constitutionalism in International Law: Comment on a Proposal from Germany, "Harvard International Law Journal" 2006, vol. 47(1), pp. 223-242.

${ }^{38}$ G. Teubner, Constitutional Fragments: Societal Constitutionalism and Globalisation, Oxford 2012.

39 N. Walker, Post-Constituent Constitutionalism? The Case of the European Union, [in:] The Paradox of Constitutionalism: Power and Constitutional Form, eds. M. Loughlin, N. Walker, Oxford 2008.

${ }^{40}$ T. Kleinlein, Constitutionalisation in International Law, "Beiträge zum ausländischen öffentlichen Recht und Völkerrecht” 2012, vol. 231, pp. 703-715.

${ }^{41}$ Ch.E.J. Schwöbel, op. cit.

${ }^{42}$ M. Louglin, What is Constitutionalisation?, [in:] The Twilight of Constitutionalism ..., pp. 47-69. 
process, going inside international law and progressively involving national constitutions as represented in a system of various sectorial regulatory regimes of international organisations and corporations - a system in which "we find (only) constitutional fragments". ${ }^{43}$

3. The interpretation of both trends as compatible: fragmentation is both a challenge and a tool of constitutionalisation; their reciprocal connection in different areas of international law is a question of "practical inquiry", and constitutionalisation itself is nothing more than a target or "a claim". ${ }^{44}$

4. The idea that constitutionalism as a concept of international law in principle cannot be used as an instrument to overcome fragmentation: beyond the state mechanisms of legal regulation (absent in international law, in contrast to constitutional), fragmentation is an instrument of normative conflict regulation rather than an instrument to overcome it. ${ }^{45}$

5. The political imagination of constitutionalism as a negative process tends to the unification of norms, interpretations and decisions based on only one (Western) legal culture. That means the reproduction of the dominant Western legal standards in the form of "neocolonial rule", ${ }^{46}$ by the exclusion of minorities or any other legal cultures. From this position, fragmentation is the natural answer to this challenge - a more positive than negative trend in international law opposed to the danger of "false universalism" implicitly present in a theory of global constitutionalism and governance. ${ }^{47}$

For many theorists, the fragmentation of international law is not a simple rejection of international law. If interpreted as a tool of normative conflict solution, it includes a variety of interpretations: as a possibility to regulate tensions between unification and diversity; as a problem of procedural character - fragmentation as a transition of technical expertise from the national to the international context; and as an interaction between rules and institutional practices culminating in the erosion of international law. ${ }^{48}$ The agreement with one or another position in this theoretical dispute means the choice of a pragmatic attitude - the strategy of some policy of law in the area of global and national constitutionalism.

43 A. Peters, Constitutionalisation, [in:] Concepts for International Law: Contributions to Disciplinary Thought, eds. J. D'Aspremont, S. Singh, Cheltenham 2017.

${ }^{44}$ Fragmentation vs the Constitutionalisation...

${ }^{45}$ R. Delpano, Fragmentation and Constitutionalisation of International Law: A Theoretical Inquiry, "European Journal of Legal Studies" 2013, vol. 6(1), pp. 67-89.

${ }^{46}$ B.S. Chimni, Third World Approaches to International Law: A Manifesto, "International Community Law Review” 2008, no. 3, pp. 3-27.

${ }^{47}$ S. Xavier, op. cit.

${ }^{48}$ R. Delpano, op. cit., p. 88. 
Pobrane z czasopisma Studia Iuridica Lublinensia http://studiaiuridica.umcs.pl

Data: 26/04/2023 15:59:00

Andrei N. Medushevskiy

\section{HOW LARGE IS THE WORLD OF GLOBAL LEGAL FRAGMENTATION? "PROTECTIVE CONSTITUTIONALISM" AS A NEW POLITICAL REALITY OF GLOBALISING WORLD}

As an important counterweight to the dominant mainstream interpretation of global constitutionalism, there are alternative projects (anti-globalism among them). Their centre of gravity concentrates on the fragmentation of international regulation in the form of global regional constitutional self-determination. The construction of global regions provides the possibility to articulate the particular characteristics of a constitutional formula combining not only common principles, but the logic of their implementation and judicial interpretation based on specific regional, cultural and historical attitudes. This approach is represented mainly by the critical school of international law ${ }^{49}$ arguing a new reality of "post-national law" as a serious danger to constitutionalism, pluralism and human rights. ${ }^{50}$ The critical school emphasizes the growing role of fragmented regional identity in following aspects: the polarisation of the global centre and periphery; the construction of a global east and a global south; ${ }^{51}$ the history of self-determination ideas and movements; $;{ }^{52}$ the reevaluation of the role of different continents: Europe, Asia, Africa, Latin America. ${ }^{53}$ A special point is a growing importance of sub-regions (as, e.g., CEE) and the impact of influential countries - the US, Russia, China - which are generally not ready to follow the prescriptions of international law in many important respects.

A part of this debate is the new preoccupation with finding a bridge between Western and Asian prospects for global constitutionalism by understanding this phenomenon from European and Asian Perspectives ${ }^{54}$ and representing Eastern models not as deviance, but as alternative liberal or non-liberal concepts. However, how is it possible? Third World approaches to international law traditionally opposed classic the "Western" liberal outlook arguing a "transcivilisational perspective on Global Legal Order" as a way to overcome "West-centric and Judiciary-centric deficits in international legal thoughts", ${ }^{55}$ and realise the so-called "post-liberal"

49 M. Bönnemann, L. Jung, Critical Legal Studies and Comparative Constitutional Law, 2005.

${ }^{50}$ N. Kirsch, Beyond Constitutionalism: The Pluralist Structure of Postnational Law, Oxford 2010.

${ }^{51}$ Constitutionalism of the Global South, ed. D.B. Maldonado, Cambridge 2013.

52 E. Manela, The Wilsonian Moment: Self-Determination and the International Origins of Anti-colonial Nationalism, Oxford 2007.

${ }_{53}$ Asian Approaches to International Law and the Legacy of Colonialism, eds. J.-H. Paik, S.-W. Lee, K.Y.L. Tan, London 2012; J. Frosini, F. Biagi, Political and Constitutional Transitions in North Africa: Actors and Factors, London 2014; S. Bhandari, op. cit.

${ }^{54}$ Global Constitutionalism from European...

${ }_{55}$ Y. Onuma, A Transcivilizational Perspective on Global Legal Order in the Twenty-first Century: A Way to Overcome West-centric and Judiciary-centric Deficits in International Legal Thoughts, "International Community Law Review" 2006, vol. 8, pp. 29-63. 
concept of human rights, property, information rights and ecology protection in transnational constitutional regulation and governance. ${ }^{56}$ The approach of Islamic countries represents an alternative way emphasizing the role of "Islamic religious values" as an integral part of the human rights agenda. ${ }^{57} \mathrm{China}$ is, perhaps, the most prominent case of a "separate way" based on a Confucian version of legal philosophy and a practice clearly opposing democracy and meritocracy as two different principles of social and legal constructivism. ${ }^{58}$ There are other paths beyond the standard European interpretations, as the particular case of Japan shows. ${ }^{59}$ In theory, it is becoming more and more evident that global constitutionalism could result not necessarily in liberal democratic forms, but provide the grounds for different international hybrid legal regimes if not for the Global Leviathan solution. ${ }^{60}$

This theoretical approach in its radical form denies even the positive role of existing international law as a predominantly "Western" construction, historically created and used by European countries for the legitimation of colonial and neo-colonial rule and domination in other regions of the world. ${ }^{61}$ This approach also demands a redefinition of the very nature of such important notions as democracy, sovereignty, rule of law, a law-based state, and minority rights, as traditionally interpreted according to Western liberal standards. This "demand for justice" for developing regions could easily be transformed into a more conservative legal ideology by using old cultural and ideological stereotypes of mass consciousness, as, e.g, the Russian post-Soviet reality has demonstrated in recent years. ${ }^{62}$ This theoretical debate implies a reevaluation or, rather a re-invention, of legal identity as a form of regional self-determination in terms of political culture, and of periphery, hybrid, or imitation regimes of "limited pluralism", "transformative regimes", "illiberal democracy", demonstrating their commitment to move from law to "real politics" and constitutional authoritarianism.

Very often, this turn in legal interpretation is interpreted as a simple backsliding of democracy - a primitive populist reaction to positive global changes and the

${ }_{56}$ M. Carducci, A. Castillo, Nature as "Grundnorm" of Global Constitutionalism: Contributions from the Global South, "Rivista Brasileira de Direito" 2016, vol. 12(2).

${ }^{57}$ C. Aydin, The Politics of Anti-Westernism in Asia: Visions of World Order in Pan-Islamic and Pan-Asian Thought, New York 2007.

${ }_{58}$ M.A. Carrai, Global Constitutionalism and the Challenge of China's Exeptionalism, [in:] Global Constitutionalism without Global Democracy..., pp. 95-113.

59 A. Kimijima, Global Constitutionalism and Japan's Constitutional Pacifism, 2011, www. ritsumei.ac.jp/acd/cg/ir/college/bulletin/Vol.23-3/03_Kimijima.pdf [access: 15.08.2021].

${ }^{60}$ Global Constitutionalism without Global Democracy...

${ }^{61}$ V. Kumar, Towards a Constitutionalism of the Wretched, 27.07.2017, https://voelkerrechtsblog. org/towards-a-constitutionalism-of-the-wretched [access: 15.08.2021].

62 A.N. Medushevskiy, Recht und Gerechtigkeit in den politischen Debatten der postsowjtischen Ara (mit Nachtrag 2017), [in:] Gerechtigkeit in Russland: Sprachen, Konzepte, Praktiken, ed. N. Plotnikov, München 2019, pp. 423-460. 
response of mass consciousness to irritating impulses such as a deficit of democracy and legitimacy, economic deterioration, migration and political instability. According to this mainstream interpretation, the global liberal constitutional agenda confronted the complex variety of new unforeseen threats but still did not provide any sufficient protection capable of stopping such regrettable developments. They involving such developments as Brexit, the conservative protectionist course of the Trump administration, ${ }^{63}$ the degradation of liberal constitutionalism in Eastern Europe (Poland, Hungary and Romania's constitutional and judicial counter-reforms) in reaction to the "post-communist project" difficulties. ${ }^{64}$ It also involves the progressive erosion of law-based states in the post-Soviet space, and in "new democracies" - India, Indonesia, Turkey, Brazil and South Africa ${ }^{65}$ The unexpected "end of post-communism" in Eastern Europe demarcated a line between stable ideological beliefs and growing uncertainty in the future in all countries of the so-called "transition to democracy area" in different parts of the world.

Perhaps the most prominent representation of this new trend could be found in the 1993 Russian Constitution. The international debate about "how large the world of global constitutionalism is" ${ }^{66}$ initially involved skeptical remarks about its subject and heuristic potential, ${ }^{67}$ and resulted in rather pessimistic conclusions. The world of global constitutionalism has become much narrower in recent years than it was in the period of "liberal triumphalism" in the 1990s. The crucial role of the West in "ruling the world" ${ }^{68}$ gradually transformed in the opposite direction, critically described as "ruling the void". ${ }^{69}$ The erosion of legal integration, the deficit of legitimacy, the vacuum of responsibility and global governance are the most visible consequences. We can agree with that diagnosis but not with its explanation. The interpretation of the deterioration of global constitutionalism and the prevalence of fragmentation over integration can scarcely be reduced to a conservative populist reaction against liberal values in order to establish authoritarian rule. A much broader set of factors should be considered. The failure of the international community to create an uncontroversial concept of future; the growing asymmetry in international relations and the information agenda; a per-

63 J. Havercroft, A.Wiener, M. Kumm, J. Dunoff, Editorial. Donald Trump as Global Constitutional Breaching Experiment, "Global Constitutionalism" 2018, vol. 7(1), pp. 1-13.

${ }^{64}$ B. Buden, Zone des Übergangs: Vom Ende des Postkommunismus, Berlin 2009.

65 T. Piccone, Five Rising Democracies and the Fate of the International Liberal Order, New York 2016; T.G. Daly, Democratic Decay in 'Keystone' Democracies: The Real Threat to Global Constitutionalism?, 10.05.2017, www.iconnectblog.com/2017/05/democratic-decay-in-keystone-democracies-the-real-threat-to-global-constitutionalism-i-connect-column [access: 15.08.2021].

${ }^{66}$ M. Kumm, A. Lang, J. Tully, A.Wiener, op. cit., pp. 1-8.

${ }^{67}$ G.W. Brown, The Constitutionalisation of What?, "Global Constitutionalism" 2012, vol. 1(2), pp. 201-228.

${ }^{68}$ Ruling the World...

${ }_{69}$ P. Mair, Ruling the Void: The Hollowing of Western Democracy, London 2013. 
ceived lack of reliable information ("fake news"); the threat of the unpredictable consequences of trans-national economics and governance; the growing suspicion of civil society toward local elites as simple translators of the global elite's orders. As a result, we have a sociologically proven demand for stability and order with growing separation between two formally similar, but substantially different concepts of global and national constitutionalism - global human rights-oriented and nation state-oriented clusters. ${ }^{70}$

All that does not mean the simple repudiation of legal globalisation but the formation of a demand for new forms which are more suitable to the format of cultural diversity, historic traditions, national interests and an appropriate timetable for reforms. In many countries, the adoption of classic constitutional standards proved their inapplicability to the complex social reality of developing countries characterised by a lower level of social integrity, an abundance of national, religious or ethnic conflicts, escalating violence, and, therefore, the degradation of fidelity to their proclaimed legal principles and norms. The dysfunctions of liberal constitutionalism in this cultural situation stimulates hybrid solutions oriented toward the search for stability and minimal predictability of society in which state power takes the principle part as a mediative force among contrasting partisan positions of internal and external players. Playing this stabilising role in the modernisation process, the state bureaucracy and national elites consider the adopted constitutional principles as a promise, but not as a binding force for the state itself, preferring to use a special theoretical explication such as "law in transformation", "transitional justice", etc.

The constitutional ideal remained, but its full practical enforcement is being postponed by many countries into the unclear future. The meaning of this trend is a conceived move from idealism to realism, from values to interests and from exaggerated beliefs toward attainable options and the possibility of protecting them legally in any possible way. "Protective constitutionalism" is, perhaps, the formula of this new international reality, which means the limited adoption of international constitutional value-standards in order to protect national "interests" - cultural identity, traditional values, economic priorities, institutional frameworks and political stability - which are challenged by new destructive global trends. Right or wrong, this is the new reality of international affairs.

${ }^{70}$ D.S. Law, M. Versteeg, The Evolution and Ideology of Global Constitutionalism, "California Law Review” 2011, vol. 99(5), pp. 1163-1258. 
THE NATURE OF THE CURRENT CONSTITUTIONAL BACKSLASH: THE EROSION OF DEMOCRATIC LEGITIMACY IN EASTERN EUROPE AS A KEY RESOURCE OF CONSTITUTIONAL POPULISM

One of the key restraints to a stable democratic process is the erosion of democratic legitimacy on European and national levels of regulation. At the core of the problem is the erosion of trust in European institutions. This "deficit of democracy" became the subject of broad international discussion, and revealed different opinions on the future of Europe. Supranational institutions were interpreted by skeptics as the imposed machinery of control over national governments, and ipso facto considered as vehicles of the centralised, unelected and nontransparent European bureaucracy. This criticism became a prominent argument in the current debate about the future of the EU and has had a real impact on the populist mobilisation in countries of CEE. ${ }^{71}$ The big problem arises in the causes and outputs of the whole transformation - the deficit of democracy is the cause of the populist reaction or vice versa, and the populist backslide articulating or even creating the ground for constitutional remission.

In countries of the Visegrad group (Hungary, Poland, Czechia and Slovakia), which were earlier at the forefront of the post-Communist democratic transition, the constitutional restoration today has reached its apex in the form of re-traditionalisation - the reproduction of some Soviet and even pre-Soviet legal stereotypes and attitudes. This conservatism includes sharp criticism of the Western model of liberal democracy, an apologia for nationalism and collectivist values, self-isolation, and an inferiority complex (in the form of historical victimisation and respective national state grandeur beliefs). It represents, in the composition of legal ideologies, recommending such remedies as the promulgation of a vague idea about the necessity to protect the cultural and religious national traditions against globalisation, westernisation or migration, a rewriting of history, a pretend constitutionalism, and authoritarianism. ${ }^{72}$

In this context, the principles of democratic legitimacy, a parliamentary system and the separation of power are in danger of deformation, stimulating populist solutions represented in different forms:

1) the establishment of the mechanical authoritarian stability through constitutional reforms (amendments) and the installation of a de facto one-party dominance in parliament with subsequent constitutional or legal counter-re-

${ }^{71}$ Constitutional Crisis in the European Constitutional Area. Theory, Law and Politics in Hungary, and Romania, ed. A. Von Bogdandi, P. Sonnevend, Oxford 2015.

72 A.N. Medushevsky, Konstitutsionnaya retraditsionalisatsiya v Vostochnoy Evrope i Rossii, “Sravnitel'noye konstitutsionnoye obozreniye” 2018, vol. 134(1), pp. 13-32. 
forms process involving the extension of the dominant party's control over another branches of power (Hungary, 2012 and Poland, 2015),

2) the reproduction of permanent political instability in the triangle of parliament-government-president (the so-called "coup" in Bulgaria, 2016, or the impeachment crises in Romania, 2014, 2017, the governmental crisis in Macedonia and Monte Negro),

3) the proliferation of attempts to correct the existing model of a monistic parliamentary system by the enforcement of presidential power (e.g., the constitutional reform in Czech Republic, 2012), or intensive debates about the radical transformation in the established form of government (constitutional debates in Poland, Romania, Latvia).

In all countries of the region, the growing political polarisation is reproduced in the following sociological trends:

1) the eroded popular trust in electoral campaigns (often their results are declared illegitimate by the opposition before the end of the elections, or immediately after them),

2) a preference for institutions of direct democracy (referendum as a strict alternative to parliamentarianism and democratic competition of political parties), or

3 ) the growing demonstration of public support for the alternative (and presumably "less corrupt") institutions of moral influence (the Church, army or a strongman "national leader" of any kind).

The restoration of the legitimacy of constitutional and parliamentary institutions and adequate political competition is, thus, the cornerstone of constitutional modernisation and a necessary precondition for the establishment of an agenda capable of overcoming the growing populist constitutional transformation.

To sum up, it is important to develop a clear vision of the EU's identity and future, based on a careful reevaluation of its constructive priorities, and a pragmatic calculation of the long-term effects of the populist reaction as a persistent factor in the integration process. The balance between the EU's integrity and separatist trends is unstable, providing the possibility for different theoretical constructions from confederation to federation, but eventually involves different legal constructions towards more or less centralised control over member-states in the interpretation of European law and jurisprudence. After Brexit, that means the acute necessity to define the EU's legitimacy based on a renovated consensus between Old and New Europe or rather on a new modality of conflict resolution. It is already evident that the retroactive populist project, as realised in some countries of CEE, has its own cultural grounds, logic and sustainability, representing an alternative vision of Europe, and should be treated as a long-term factor in the European integration/ disintegration constitutional power-game. 


\section{THE LOGIC OF THE GLOBAL LEGAL TRANSFORMATION IN CENTRAL AND EASTERN EUROPE}

Global integration, as a process and a result of flexible inter-state agreements, does not include any independent supra-national regulation per se, nor provide the possibility for different views on the role and place of the nation state in global governance and multilayered constitutionalism. For globalists this place should be reduced to its historical minimum if not eliminated in future; for their more traditional opponents, this place should be retranslated in a new system of transnational regulation. The crucial point is to define which level of multilayered constitutionalism should have priority - global, transnational, regional, domestic, or their combination in different sectoral constructions. This debate on the scope and prospects of the national state vs. international organisations became the crucial factor for the dramatic separation of ways between the liberal mainstream, and the populist movements which spread all over the world in the 2010 s. $^{73}$

The rise of populist movements appeared to be a "common challenge" 74 to the established liberal democracies like the UK (Brexit), the US (Trump administration), the EU, as well as developing democratic countries like Brazil, India and South Africa. They could be found in global regions, like Caribbean Commonwealth countries, which were parts of the former colonial empires - British, French or Dutch and now shared some problems of the European Union as its partners or integral parts of some member-states. Here the commitment to self-consolidation reflects not only common anti-globalist protest but also the search for a special post-independence situation with regard to the legal continuity of precolonial, colonial and postcolonial periods. That makes important the crosscutting influences of different European legal traditions, indigenous law and transitional priorities in form of legal "creolisation" and other special local doctrines and practices. ${ }^{75}$ In the European context, this trend to combine and assimilate different legal traditions has specific implications in CEE and former parts of the USSR regarding their common geo-political place, cultural traditions, and historic experience under Soviet domi-

${ }^{73}$ Populism as a Common Challenge...; G. Ekiert, Three Generations of Research on Post-Communist Politics - a Sketch, "East European Politics and Societies" 2015, vol. 29(2), pp. 323-327; S. Erlanger, In Eastern Europe, Populism Lives, Widening a Split in the E.U., "The New York Times", 28.11.2017, www.nytimes.com/2017/11/28/world/europe/populism-eastern-europe.html [access: 15.08.2021].

${ }^{74}$ R. Eatwell, M. Goodwin, National Populism: The Revolt Against Liberal Democracy, Rindle 2018; A.N. Medushevskiy, Populism in the West and in Russia ..., pp. 47-57.

${ }^{75}$ The Oxford Handbook of Caribbean Constitutions, eds. R. Albert, D. O'Brien, S. Wheatle, Oxford 2020. 
nance or an imperial past. The importance of the cultural dimension of conservatism is obvious, while not identical in different global regions, sub-regions or countries. ${ }^{76}$

Important basic prerequisites for this mental transformation include the progressive conflict between positive law and fairness; a reevaluation of the historical tradition of global civilisations, regions and countries, combined with the search for a new cultural integrity and specific legal identity. ${ }^{77}$ This research strategy involves the systematisation of contested global narratives on security matters and mutual misperceptions in international and reciprocal affairs. ${ }^{78}$ It involves the analysis of citizens' growing mistrust towards multilayered constitutionalism, local governments and elites, which are presumably incapable of protecting their respective countries or groups from global problems and challenges or from undesirable transformations of the political regime. ${ }^{79}$

The current populist protest against global (European) constitutionalism is based on the hyperbolised and oversimplified interpretation of the so-called "constitutional identity" of countries, "partisan constitutionalism", overrepresented "national sovereignty", carefully cultivated peculiar national traditions of legal regulation, which are partly real, partly artificially re-invented, or introduced by governing political forces in the interest of self-preservation. ${ }^{80}$ This kind of constitutional thought became the main ground and the predominant legitimising motive for the resistance of anti-globalist forces and conservative national elites to global and European constitutionalism regarding the scope, intentions and goals of the supra-national legal regulation of national affairs.

The new situation in the EU, provoked by the rise of a conservative populist movement, fixed the point of bifurcation of the conflicting and overlapping principles of European integration, covering the meaning of constitutional values, its interpretative strategies and the agendas of the current constitutional reforms (or counter-reforms). The main question here is whether the revisionist state group of CEE remains a sustainable part of the European constitutional commonwealth or

${ }^{76}$ G. Pop-Eleches, B. Tucker, Europe's Communist Regimes Began to Collapse 30 years ago, but Still Shape Political Views, "Washington Post", 12.11.2019, www.washingtonpost.com/politics/2019/11/12/europes-communist-regimes-began-collapse-years-ago-still-shape-political-views [access: 15.08.2021].

77 A.N. Medushevskiy, Law and Revolution: The Impact of Soviet Legitimacy on Post-Soviet Constitutional Transformation, "Telos" 2019, vol. 189, pp. 121-135.

78 Security Narratives in Europe: A Wide Range of Views, ed. W. Zellner, Baden-Baden 2017; Russian-Western Blind Spots: From Dialog on Contested Narratives to Improved Understanding, Berlin 2019.

79 A. Sajó, R. Uitz, op. cit.; P. Cubicek, Regime Transitions and Variation in Post-Communist Europe, 2.04.2020, www.oxfordbibliographies.com/view/document/obo-9780199756223/obo9780199756223-0115.xml [access: 15.08.2021].

${ }^{80}$ A Quarter Century of Post-Communism Assessed, eds. M.S. Fish, G. Gill, M. Petrovic, London 2017. 
whether they already stand apart and are in the process of formulating their own "genuine", i.e. separate, concept of European constitutionalism. How can the integrity of the EU persist in the face of new global challenges for economics, society and security, ${ }^{81}$ variety of perspectives ${ }^{82}$ and the progressive divide in European values and their fulfillment in Eastern Europe? ${ }^{83}$

Constitutional re-traditionalisation, fixed in new legislation, embraces all the vital elements of human rights in CEE:

- the gradual revision of liberal legal values in order to keep the "historic identity" (the word "liberalism" has become more and more pejorative in many countries of the region),

- the new (or, rather, old) interpretation of state sovereignty as opposed to international human rights regulation (with a respective diminishing role of constitutional courts),

- the deep rethinking of the authentic liberal notions of the people's sovereignty and the civic nation toward more nationalistic if not ethnic constructions, combined with visible discrimination against national minorities (Hungary, Poland, Romania, Baltic countries),

- the subsequent rejection of state neutralism in religious matters (the new interpretation of "hate speech" in Hungary),

- the revision of family, sexual and reproductive rights (a series of constitutional amendments adopted in Slovakia, Hungary, Poland, Romania, Croatia, Latvia, Lithuania in 2013-2017 as opposed to the amendments adopted in West European countries in the same period),

- a more politicised interpretation of the international treatises which formed the basis for the new constitutional balance in some Balkan countries, Bosnia-Herzegovina (Dayton agreement), Macedonia (Ohrid agreement) and Kosovo (Ahtisaari plan) with prospective ethnic and political destabilisation in this region,

- the growing trend toward self-isolation and a limitation of the "openness" of CEE (the spontaneous reaction to migration crisis in Hungary, Czechia, Romania and Poland),

- systematic efforts to neutralise the influence of earlier accepted international humanitarian law over national constitutional legislation under the pretext

${ }^{81}$ Europe and Globalisation: the Dangers and the Assets 2013, 2.12.2013, www.robert-schuman. eu/en/european-issues/0296-europe-and-globalisation-dangers-and-assets [access: 15.08.2021].

82 J. Techau, For Predictions on the Future of Europe, 12.01.2016, https://carnegieeurope.eu/ strategiceurope/62445 [access: 15.08.2021].

83 J. Henley, 30 Years after Communism, Eastern Europe Divided on Democracy's Impact: Pew research reveals very different views on whether countries are better off today, "The Guardian", 15.10.2019, www.theguardian.com/world/2019/oct/15/30-years-after-communism-east-europeans-divided-over-democracys-impact [access: 15.08.2021]. 
of protecting the national culture or legal tradition, and the recent practical COVID-19 pandemic restrictions,

- the respective limitation of the role and independence of constitutional justice and the courts in national legal systems,

- new official rhetoric on important cultural matters regarding the reinvention of conservative cultural and religious stereotypes, a new historical memory agenda, a rewriting of history and the cult of the powerful national state or leader. The moralisation of political rhetoric by dominant mass media seems to be the other side of the same coin - the substitution of true journalism and analysis by emotional exclamations based on very simple arguments, rumours and superstitions.

These trends of conservative restoration, as the Venice Commission pointed out in its various opinions, illustrate the growing level of deviance of the national jurisdictions from the European Charter, the Lisbon Treaty and important conventions on human rights. What limits does this process of constitutional restoration have? Is it still possible to speak about an undivided concept of European constitutionalism? The answer is not clear and depends on who determines (and how) the essence of European values and the scope of the discretional power of national governments to interpret it. Could it be a new constitutional assembly created for the re-invention of the European Commonwealth, European parliament, a system of new inter-state agreements, the European Court of Justice, ECHR, or European civil society in formation? The answer is crucial for the destiny of the European integration project and for the future of global constitutionalism, European law and governance.

\section{PECULIARITIES OF THE POST-SOVIET CONSTITUTIONAL SETTLEMENT DELAY FROM A COMPARATIVE PERSPECTIVE}

The constitutional development of the post-Soviet area in a narrower sense (former republics of the USSR) has some particular characteristics in comparison with Eastern Europe and the wider world. ${ }^{84}$

We cannot trace here the regular cyclical evolution of constitutionalism because of its uneven and superficial character and the role of contradictory external and internal influences. Legal and institutional instability is perhaps the most important common feature of post-Soviet constitutionalism, which looks like a "permanent constitutional fever". ${ }^{85}$ That definition means the feeling or common perception of the presence of some important peculiarities in comparison to more stable CEE:

${ }^{84}$ Constitutional Politics in Central and Eastern Europe, eds. A. Fruhstorfer, M. Hein, Berlin 2016.

85 A.N. Medushevskiy, Tendentsii postsovetskich politicheskich rejimov v svete noveisheiy volny konstitucionnych popravok, "Obschestvennye nauki I sovremennost" 2018, no. 2, pp. 49-65. 
1) a great variability of the constitutional models under consideration in the formative period which illustrates the "privilege of retardation" - the theoretical possibility of adopting any kind of models in spite of their different historical origin, based on different legal cultures, and to transplant them from more advanced countries or, rather, to have the historical possibility of experimenting with them,

2) the often rapid and unpredictable changes of constitutional priorities - from their partial corrections until the adoption of models which had been rejected as inadmissible,

3 ) the abundance of constitutional amendments to each adopted constitution, often without great respect for the formal procedures of amendment which show the absence of a deeply rooted constitutional culture,

4) the absence of stable and neutral constitutional justice,

5) the unresolved question of the finality of crucial constitutional solutions: after the adoption of every new constitution or amendment the debates normally continue, providing new projects and proposals. This "constitutional game" resembles a form of political self-identification for political parties or groups rather than coherent and substantive legal discourse.

Another important feature of this unstable catch-up in institutional design is the lack of solid common ground for constitutional development and its aims. All countries rejected the Soviet model of nominal constitutionalism after the collapse of the USSR. The main starting point for constitutional modernisation in the region was the Russian Constitution of 1993. Being designed as a temporary constitutional settlement for the transitional period, this constitution produced an original synthesis of liberal legal guarantees (based on international human rights treatises), and a rather authoritarian construction of the presidential power interpreted as the main force and the guardian of the irreversibility of democratisation. Formally, the adopted form of government was similar to the presidential-parliamentary model of the French Fifth Republic but avoided some important checks and balances of this system. In reality, this construction paved the way for a system of plebiscitary authoritarianism with overrepresented presidential power and personified rule. This "authoritarian component" of the Russian constitutional and political system was the main problem for all post-Soviet political debates, and remained the main theme for all current projects of constitutional modernisation. ${ }^{86}$

The internal contradictions of the Russian constitutional model opened the way for different if not opposing constitutional interpretations in post-Soviet countries in favour of more liberal (parliamentarian), or more authoritarian (presidential) principles covering a great variety of national experiments inspired by the Russian

${ }^{86}$ V. Milov, A. Medushevskiy, I. Zaslavskiy, Constitution and Economy after Putin: A Roadmap for a New Russia, Washington 2018, pp. 19-31. 
version of mixed government. The separation of ways in regional constitutional development makes it possible to identify three main strategies:

1) the "colour revolutions" as the direct and law-breaking alternative to the Russian constitutional model (Moldavia, Georgia, Kirgizia, Ukraine before 2014, Armenia in 2016),

2) gradual constitutional reform inspired by authoritarian government for self-preservation in power (Kazakhstan, Uzbekistan after 2014),

3 ) the maintenance of mechanical legal stability without substantive constitutional reforms or with the presence of quasi-reforms fulfilled by the use of cosmetic changes (Azerbaijan, Belorussia, Turkmenistan, Uzbekistan before 2014).

The reciprocal influence of two factors - the constitutional design and the political regime - is the subject of debates in legal and political science literature. The change in the form of government (e.g., the move from a presidential to a parliamentary) could be proof of real regime liberalisation, or could symbolise the deterioration of democracy if used only for the protection of the established elites in power. It could even be both: some constitutional reforms taken in favour of a parliamentary system could be initiated by the ruling president in order to keep him in power as prime minister but resulting in a deeper political transformation (e.g., Georgia and Armenia). This interconnection between the legal and political parameters of the reform agenda reveals important common characteristics of constitutional modernisation in CEE interpreted as the "Paradox of Power" - the coexistence of formally strong authoritarian rule with the logic of "state weakness in Eurasia". ${ }^{87}$

From the perspective of global constitutionalism, the post-Soviet region has its own and very specific place, comparable in some way with postcolonial countries, or the countries which instantly obtained their independence after the collapse of the USSR. The countries of this region demonstrated a commitment to accept the mainstream democratic principles becoming a part of the international constitutional consensus. They show a clear intention to transform or reduce the binding force of some important international values or principles in order to adopt them for the purposes of new-created national states, and the existence of a broad spectrum of threats and hesitations regarding the protection of unstable sovereignty and legitimacy of states and political regimes from various external and internal influences.

Like a cardiogram, the constitutional development of the region reacted almost reflexively to different impulses coming from the most powerful actors in the region, Russia, the US, the EU and China, and in some cases Turkey and Iran. In these constitutional experiments, the post-Soviet region could play an important role in the selection of transplanted models, their adoption, assimilation, hybridisation, evaluation and practical implementation in very different cultural contexts.

\footnotetext{
${ }^{87}$ J. Heathershow, Paradox of Power: The Logics of State Weakness in Eurasia, Pittsburgh 2017.
} 


\section{THE RUSSIAN FORMULA OF CONSTITUTIONAL REVISION: A MOVE TO CONSTITUTIONAL DICTATORSHIP?}

Constitutionalism in unstable, transitional, hybrid and authoritarian regimes became a special area of investigation of lawyers and political scientists as a global phenomenon in recent decades, centring on the post-Communist region. ${ }^{88}$ The concluding phase of the Russian post-Soviet legal transformation coincided with a deep reevaluation of the legitimacy of the political regime as represented in the 2020 constitutional reform. This reevaluation started much earlier and became a natural part of the conservative political romanticism formed after the collapse of the USSR as the predominant official reaction in the post-Soviet society and elite after $2000{ }^{89}$ This reevaluation overwhelmed the Russian constitutional and legal development of the last decade..$^{90}$ The systemic revision of the Russian constitution established in 1993 formally represented a set of concrete amendments to the text of the 1993 Constitution made in formal accordance with amendment procedures. The 2020 constitutional reform also revised the legitimacy formula of the Russian political regime in five main directions.

First, the reconsideration of the positive and negative legitimacy criteria in terms of space, time and the sense of social being. The liberal ideological paradigm, which prevailed in the period of constitution-making, was strictly reduced by the reform provisions in several key aspects:

- the replacement of the spirit of global constitutionalism based on the idea of "universal human values" by a commitment to restore "traditional values", and rehabilitate the presumably lost spirit of "national sovereignty",

- a shifted balance of international and national constitutional law - the adoption of the amendment giving the Russian Constitutional Court the power to nullify decisions of transnational courts if they contradicted the national constitution,

- the adoption of new norms transforming the rational-legal legitimacy of power by using new, value-oriented cultural or identity terms: national destiny, historical tradition, religion, traditional family values, language, territorial identity, and patriotism. The essence of this ideological transformation in concentrated form represented the idea of "elite nationalisation". This was a set of new provisions prohibiting dual citizenship for all state and

${ }^{88}$ Constitutions in Authoritarian Regimes, eds. T. Ginsburg, A. Simpser, Cambridge 2014.

89 Power and Legitimacy: Challenges from Russia, eds. P.-A. Bodin, S. Hedlund, E. Namli, London-New York 2012.

90 A.N. Medushevskiy, Russian Constitutional Development: Formal and Informal Practices, "BRICS Law Journal" 2019, vol. 6(3), pp. 100-127; idem, Constitutional Reform in Russia: Substance, Directions and Implementation, "Forensic Research and Criminology International Journal" 2019, vol. 7(6), pp. 286-294. 
municipal officials in order to reduce the cosmopolitan orientation of the elite and to put the West-oriented opposition beyond the political process.

Second, a reevaluation of substantive and instrumental legitimacy in terms of a new "social contract" between society and political power, and a set of practical measures to reinstall it on a new conceptual basis. The new formula of social consensus introduces a new equilibrium between the liberal ideology of the market economy and a new ideological construction of social solidarity. This concept, incorporated into the text of the new constitution with new amendments, treats solidarity issues in terms of social responsibility, and a social partnership between business and the state. It creates a new balance between rights and responsibility, reintroducing respect for "working people", and the establishment of neo-paternalist control of the state over social policy priorities (by a fixed minimal wage, pensions and social security measures) in order to guarantee sustainable economic development. This conceptual transformation of constitutional norms provides a new legal foundation for the restoration of the social responsibility of state - a corporatist or state-capitalist system including elements of social paternalism and institutions of mass mobilisation under government control and supervision.

Third, a revision of the balance between different levels of legitimacy in the framework of a federalist state: federal, regional and local. In the block of amendments this is realised by the constitutional adoption of a new conceptual formula on the "entire system of public power": the sovereign power of a political union embracing the whole country and functioning as a complete system in constitutionally determined, concrete organisational forms. The legal and political parameters of this organisation, as clarified by amendments to correct the Russian federal system in three major aspects: the federal centre becomes more powerful; subjects of Federation becomes less powerful; and local self-government becomes totally integrated into the "power vertical". The system of public power has been completed by an important transformation of Russian bicameralism produced by the cumulative effect of constitutional amendments concerning new procedures for the formation of the Upper Chamber, the creation of the State Council as a new institution of mediation and coordination, and granting new important prerogatives to the Constitutional Court in the area of regional legislative control. In this system of neo-Imperial rule, all conflicts between different levels of government are solved by political decisions according to the principle of the entire system's "functional unity".

Fourth, the contradiction between the legitimate purposes and institutional mechanisms of power implementation. The declared legitimate purpose of the reform included such items as the development of civil society, the growth of political competition, direct and representative forms of democracy, and the role of parliament (the State Duma) in the separation of powers. In spite of some corrections to all branches of power introduced by amendments in order to maintain 
their reciprocal institutional flexibility, the main undeclared result of the reform is in the concentration of power. This result has been achieved by the delegation of important prerogatives of all branches to one super-power institute: the head of the state as the legitimised centre of the whole system of public power and the highest arbiter in all institutional conflicts. The key innovation is the formal constitutional adoption of presidential control over the government and its responsibility only to the president. That means a definite shift from the dual or mixed form of government (formally established in 1993) to a quasi-presidential system of government (because the system's lack of checks is adequate for a standard presidential system).

Fifth, the constitutional amendments change the balance of constitutional and meta-constitutional power legitimacy. The constitutional parameters of the legitimacy of the head of state take their origin from formal constitutional norms and their judicial interpretation; meta-constitutional prerogatives of presidential power come from its symbolic role in the public space, in international diplomacy and in the resolution of social, national and political conflicts. The constitutional amendments create grounds for a new type of legitimacy combined in one legal and extra-legal form by fixing a new very broad meta-constitutional legitimacy - the responsibility of the president for maintaining "civil peace and national agreement" in the country. This statement is remarkably similar to provisions of some other post-Soviet countries with authoritarian political regimes. Following these, the amendments introduced practically unlimited power for the head of state and immunity during and after his stay in office, crossed the border between legal and personal legitimacy, and opened the way in practice to an unlimited stay in power. In sum, this system could be defined by using the term "constitutional dictatorship", ${ }^{91}$ a system of government, where the transformation of the constitutional order is made on the basis of the existing Supreme Law, the agreement of society (demonstrated in a plebiscite form) and the unanimous support of all branches of power in order to establish the unlimited power of the presidential office, personified in the figure of the actual leader.

The legitimacy formula introduced by the 2020 constitutional amendments is internally contradictory: it combines a constitutionally determined political system with extra-constitutional (namely cultural) parameters including history, nation, solidarity, overrepresented public power, and the symbolic (meta-constitutional) status of the head of the state. The system of constitutional values has been transformed by shifting the balance of international and national law, positive and negative legitimacy and reduced to administrative tools of enforcement. In this formula the sovereign (people) delegate, formally and democratically, its power to the head of the state, conducting ipso facto the role as its sole and permanent representative

${ }^{91}$ Idem, Perechod Rossii k konstitucionnoy dictature: razmyshleniya o znzchenii reformy 2020 goda, "Sravnitel'noe konstitucionnoe obozrenie" 2020, vol. 136(3), pp. 33-50. 
in power. The constitutional reform fixed important "pragmatic" legal changes, introduced in the previous decades regarding the conservative revision of the 1993 Russian Constitution's liberal impetus, and resumed a new legal reality - a neo-imperial state with a plebiscitary political regime. This reconstruction of power is in full accordance with the logic of the restoration of historical periods concluding the post-Soviet constitutional cycle, namely, its third phase - reconstitutionalisation (a reversed interpretation of the initial sense of constitutionalism on the grounds of a purely restoration logic).

\section{LAW AND POLITICS: THE EVOLVING ROLE OF THE CONSTITUTIONAL JUSTICE}

The populist turn in CEE actualised the role of constitutional justice in the protection of the liberal democratic institutional system. Institutions of constitutional control play a twofold role in constitutional settlement: they are known as a neutral legal instrument of constitutional interpretation ("oracles of the law"); and they also represent an important branch of the separation of powers, perhaps the "least dangerous" one, but still an element of the political system. In this last, they cannot avoid references to general moral values, principles. Activist engagement in political confrontation over the legal priorities of each respective country ${ }^{92}$ becomes a subsequent actor of politico-legal dynamics ${ }^{93}$ from a national and transnational perspective. ${ }^{94}$ That makes Constitutional Court a real centre of the legal policy formation, actualizing the problem of its place in the system of separation of powers, institutional independence and judicial interpretation of constitutional principles and norms in all countries under consideration.

This situation (since the famous debates between Hans Kelsen and Karl Schmitt in the Weimar republic) is normally described as the dilemma of a judge's choice between two opposite modes of judicial behaviour - the juridisation of politics or the politicisation of law. Today this dilemma is no less important than before: the growing social polarisation, "partisan constitutionalism" and the populist revision of constitutional principles highlighted the role of an independent, neutral and transparent judiciary. The new situation can also explain why institutions of constitutional control have become the main target of populist initiatives in the sphere of legal policy. They are usually made under the convenient pretext of democratisation,

\footnotetext{
${ }_{92}$ V.C. Jackson, Constitutional Engagement in a Transnational Era, Oxford 2010.

${ }_{93}$ T. Roux, The Politico-Legal Dynamics of Judicial Review: A Comparative Analysis, Cambridge 2019.

94 Constitutional Courts: Judicial Roles in Global Perspective, eds. D. Kapiszewski, G. Silverstein, R.A. Kagan, Cambridge 2013.
} 
which is interpreted as the restoration of the lost "genuine" popular (or national) sovereignty and a revival of the direct social control over elites. "Juristocracy", ${ }^{5}$ following this logic, is a tool of elite dominance and thus should be transformed into a more appropriate democratic system of jurisprudence under the control of a parliamentary majority. A part of the new theoretical explanation of this trend is represented, for example, in the concept of "popular constitutionalism" as opposed to the "aristocratic nature" of constitutional courts as unelected institutes of "juristocracy", or, recently, in the demand to "take the constitution away from courts" (in the US). This degradation of trust in national constitutional jurisprudence in many countries where populism is a real political force has also another side. The commitment of national elites to stop or limit unpleasant international influences (e.g. the precedents of transnational courts) which can reduce the scope of political control of populist governments over domestic constitutional development is fully in accordance with the presumed and carefully protected fragmentation logic.

The responses given to this challenge in CEE during the 30 years of post-Soviet transformation enable a reconstruction of three major ideal types of constitutional justice by "policy of law":

- constitutional courts as an effective barrier against populist demands. This attitude is manifested by many courts, for example, during the first stage of the transitional process, in order to delegitimise anti-liberal collectivist and egalitarian demands and to dismantle market economy principles,

- courts as formally impartial players. In some cases, which look like the silent adoption of a modified version of the American Supreme Court's "political question doctrine", the readiness to remain neutral in the competition for power among branches, and avoid decisions in some explosive cases by delegating the power to decide to other, "political", branches - parliament or government. This type of court behaviour is demonstrated, for example, in the treatment of some complex aspects of the admissibility of "opportunist" political coalitions between parties with opposite ideologies in order to protect their control over a divided parliament,

- courts as non-independent and even active transmitters of the populist course into the national legal system. This type of behaviour involves different and even polar attitudes, from the adoption of the neutrality principle to activist "silence" in marginal situations which include a skillful combination of different legal and political intentions and arguments (political arguments disguised as legal ones is only one method of populist jurisprudence).

The lack of stability, independence and neutrality in constitutional jurisprudence in CEE parliamentary democracies could be partly explained by the historic

${ }_{95}$ R. Hirschl, Towards Juristocracy: The Origin and Consequences of the New Constitutionalism, Cambridge 2004. 
combination of three main parameters: uneven constitutionalism, the adoption of the Kelsenian model of abstract control of constitutionality, and the nomination of justices reserved for only one branch of power, namely, parliament. The combination of these three parameters creates a peculiar background for the potential backsliding of independent jurisprudence. The abstract control prerogative makes courts the true policy makers in constitutional matters, but this power could be monopolised by the dominant parliamentary majority through the selection and nomination of judges, thus, under the strict control of the legislative branch. In the absence of other checks and balances, on different historical or sociological grounds (or their progressive erosion in a populist revision), the systemic transformation could result in the eclipse of liberal constitutionalism.

The political interpretation of justice, as demonstrated by many analysts, has been clear in Hungary (since 2012) ${ }^{96}$ and Poland (since the constitutional crisis of 2015), ${ }^{97}$ but also is quite visible in other countries of the region. The wave of new constitutional and legal amendments inspired and sponsored by the EU in Albania (2008, 2015-2016), Bulgaria (2015), Romania, and Serbia in the last ten years reconsidered and highlighted the importance and role of constitutional courts in their respective countries but reportedly did not achieved the full-scale independence of judicial power.

The radical transformation of the Russian Constitutional Court was the result of the 2020 Constitutional amendment as well. The court apparently received new and important prerogatives in the policy of law formation. The constitutional court now has the power to check the constitutionality of all laws, including laws on constitutional amendments, just before the president signs them; to nullify the decisions of international courts, made on the grounds of ratified international treatises if they are considered contradictory to the national constitution; to constitutionally control the legislation of the Federation's subjects before it is adopted by regional powers; to becomes the highest arbiter in legislative controversies between parliament and the president. However, this visible growth in the political importance of the constitutional court coincided with another group of changes, provisions on the nomination and resignation of justices, new procedures of deliberation and decision-making, which in sum made this institution more dependent on and controlled by presidential power.

This trend toward politicised jurisprudence is represented even more clearly in all countries of the former Soviet space: the last wave of constitutional amendments

${ }^{96}$ Constitutional Crisis in the European Constitutional Area...

${ }_{97}$ M. Matczak, Poland's Constitutional Crisis: Facts and Interpretations, The Foundation for Law, Justice and Society Policy Brief 2018; K. Szczypska, Further Erosion of the Polish Democracy: Providing Feedback for the First EU Rule of Law Report, 5.05.2020, https://en.odfoundation. eu/a/26796,odf-welcomes-persecuted-polish-judges-and-prosecutors-in-brussels [access: 15.08.2021]. 
demonstrated the diminished priority of international law, the growing deviances from formally adopted standards of rule of law, and the subsequent reinterpretation of the constitutional justice neutrality principle. The formal pretexts for this reinterpretation could differ and involve application to the real challengers - the restoration of traditional religious values, state security enforcement against terrorist threats, migration crises, the degradation of governability or anti-corruption measures. Hence, the displacement of the constitutional jurisprudence and its devaluation has a very important undeclared component - the search for political stability by the new power-hungry political forces in political and constitutional re-traditionalisation.

That explains the bulk of dubious initiatives in the countries under consideration:

1) the restoration of "lost sovereignty" via constitutional amendments, approved to reconsider the place of the international conventions and ECHR precedents in domestic legal regulation,

2) the revision of laws regulating the status, prerogatives and functions of constitutional courts, or the procedures of nomination and denomination of the justices,

3) the transformation of the institutional design of the constitutional jurisprudence as such.

Some countries (Kyrgyzstan, Georgia and Ukraine) experimented with the hybridisation of different international models, the replacement of constitutional courts with supreme courts, or their combination in one institution without any regard to the legal and historic specific features of Anglo-Saxon or continental systems of law, the structure and hierarchy of sources of law, etc. That made it possible to describe solutions with simple political arguments. Ironically, the main argument in many such cases was the de-politicisation of the court nexus to make it independent from political pressure and avoid the influence of the former political forces.

Many preoccupations still exist about the role of "agreements" and bargaining in legal decision-making regarding the formal and informal practices of the branches of power, political parties and different interest groups. Some of them are incorporated into the disguised populist agenda of the legal transformation based on conservative political romanticism, a nationalistic xenophobic identity, authoritarianism, or involve the direct protection of ethnic clans and oligarchic groups in power. Dialogue is important, ${ }^{98}$ but dialogue between whom? European citizens and supranational institutes? different regions of Europe or, rather, national

98 M. Rosenfeld, Global Constitutionalism: Meaningful or Desirable?, "European Journal of International Law" 2014, vol. 25(1), pp. 177-199; S. Bartole, Comparative Constitutional Law - an Indispensable Tool for the Creation of Transnational Law, "European Constitutional Law Review" 2017, vol. 13(4), pp. 601-610. 
governments? branches of power? European and national constitutional courts? Could this dialogue be resumed in the rebuilt of trust in the European integration project and its judicial instruments on new cultural, political or legal grounds?

\section{GLOBAL CONSTITUTIONALISM: CONFLICT PERSPECTIVE ANALYSIS}

Conflict Perspective Analysis (CPA) is one mediation method. It reveals the positions of the conflicting parties, clarifies differences in positions and gives an understanding of the arguments and feelings of the other side. This method reveals the parties to the conflict in such a way that they can better see the strong and weak arguments (or vulnerability) of another side. Understanding and accepting this vulnerability provides an opportunity to move toward conflict resolution. The advantage of this method is that it does not initially require the conflicting parties to work on a resolution of the conflict itself. The understanding and acceptance of the features of one's own and the other are at the centre of the method. This approach makes it useful in complex or protracted conflicts, when the parties may refuse to work on resolving the conflict, but nevertheless agree to somehow settle and figure out what is happening when they are not satisfied with the conflict situation. The immediate solution of the conflict may be a consequence of the use of this method, but is not its direct goal. CPA is a very useful instrument for the integration/ fragmentation dilemma, using the systematisation, evaluation and criticism of argumentation from both sides in constitution-making in the transnational legal order. ${ }^{99}$

A practical tool for a better articulation of the polarised positions in the debate on global constitutionalism and fragmentation is narrative mediation for structuring dialogues about contradicting narratives. This dialogue is possible based on the meta-narratives of legal globalisation and fragmentation created by two sides expert-groups from different global regions, countries, international and national institutions. These two narratives as represented and reflected in the literature and the statements and projects of global constitutional transformation should have comparable points and similar questions, ${ }^{100}$ paving the way from shared truths to joint responsibility. ${ }^{101} \mathrm{CPA}$, based on contested narrative mediation, includes seven

${ }^{99}$ Constitution-Making in Transnational Legal Order, eds. G. Shaffer, T. Ginsburg, T.C. Holliday, Cambridge 2020.

${ }^{100}$ R.J. Millard, Adopting Narrative Mediation in Protracted International Conflict: Transcending the Relational and Emotional Hurdles to Resolution in Inter-group Conflicts, 2008, http://hdl.handle. net/1794/8643 [access: 15.08.2021].

${ }^{101}$ D. Splinter, L. Wuestehube, From Shared Truths to Joint Responsibility. Training Manual for Mediators and Dialog Facilitators, 2017, www.inmedio.de/sites/default/files/training_manual_for_mediators_and_dialogue_facilitators_nepal_withouttrack_changes.pdf [access: 15.08.2021]. 
stages: presentation; actors; facts; background interests and motivation; options; reality check; new discoveries. ${ }^{102}$

Presentation: at this stage, the parties determine what the opposing positions are. In this research, the two meta-narratives are represented by the conflicting parties - supporters of global constitutionalism and supporters of global fragmentation - as different ways of international legal integration. This division has an instrumental character and is used here only to provide a clear articulation of difference between them.

The first party's approach in favour of global constitutional integration can be summarised in the following main arguments:

1) the formation of transnational constitutional norms (such as the UN Charter or the principles and norms of European law) guarantee individuals a direct down-up approach to law and the possibility of avoiding traditional state bureaucracy,

2) the origins of multi-layer constitutionalism (international, regional, domestic and local levels) is the basis for a new system of the vertical separation of powers more compatible with global democratic priorities beyond state borders,

3) the creation of new multi-constitutional or quasi-constitutional frameworks, sometimes labeled as "soft law", challenges the traditional balance of power between states and makes the direct dominance of one powerful state more difficult,

4) the promotion of more intensive dialogue between transnational and national parliaments and courts is of crucial importance in order to stimulate democracy on different levels of the global governance system (international, regional, national and local),

5 ) in the future, that means the gradual departure from key principles of the Westphalian system of international order towards a new system, based on transnational norms and institutions.

Fragmentation supporters present another group of arguments:

1) if realised, global constitutionalism means the total unification of global legal regulation, dissolving important cultural, regional and historical peculiarities,

2) multi-layer constitutionalism, in reality, means the complication of legal regulation inhibiting the adequate fulfillment of rights,

3) transnational constitutional regulation is only possible if there is a global civil society. At the current stage, there is no empirical proof of this: constitutional processes are possible only based on national civil societies, sovereign

${ }^{102}$ Inmedio's Conflict Perspective Analysis (CPA). Conflict Analysis Tools - Center for Security Studies, 2020, www.css.ethz.ch/content/dam/ethz/special-interest/gess/cis/center-for-securities-studies/pdfs/Conflict-Analysis-Tools.pdf [access: 15.08.2021]. 
states or their regional or global cooperation in international affairs. The real problem is the undermining of democratic participation as result of the sovereign prerogatives of national states moving to the supra-national level,

4) multi-level institutional dialogue is not a solution. The transfer of national prerogatives to unelected supra-national bureaucratic institutions and courts demonstrates the erosion of national democracy and the substitution of parliamentary rule by the "government by judges",

5) these developments resumed in the "deficit of democratic legitimacy" as result of the pressure of the most powerful international actors on sovereign states and minorities.

Challenge: while differentiating the positions, there is a danger of artificially sharpening those positions resulting in a "black-and-white" polarity, opposing integration and fragmentation. In reality, the picture is multifaceted and some positions in that debate diverge more, some less.

Actors: at this stage, the parties determine who the main actors are, who creates and maintain these positions, making them defined and stable for a long time. Legal globalisation produced new factors in the division of international affairs and the system of new diversified actors with different or even controversial interests sectorial regulatory regimes, international organisations, NGOs and transnational corporations, academic think tanks and more or less independent groups of political activists acting in parallel with traditional actors - national states and governments.

Their positions are reflected by three groups of intellectuals, one group, who strictly support global constitutional integration, another, who support constitutional fragmentation as clear alternative to the globalist solution, and the third, who seek a compromise between such polarised statements to find any practical solutions to the conflict. ${ }^{103}$

These academic positions represent contrasting visions of the future global order and ways towards its creation:

1) the global constitutionalism project, which focuses on the constitutionalisation of international law as a rational target-oriented policy of legal constructivism, supported by the main trans-national actors, global civil society, international organisations, corporations and some states,

2) the global fragmentation project, which focuses on sovereignty, regional self-organisation and the protection of the cultural and legal identity of global regions and civilisations, if not separate states,

${ }^{103}$ In Europe, after Brexit, this separation of opinions in society and elites of EU Member States is clearly represented by three groups of emotional and intellectual attitudes - Eurooptimism, Europessimism, and Eurorealism. See T. Rainers, M. Goodwin, D. Cutts, The Future of Europe: Comparing Public and Elite Attitudes, London 2017. The article of A. Möller and D. Pardijs (The Future Shape of Europe, https://ecfr.eu/special/the_future_shape_of_europe [access: 15.08.2021]) include contrasting interpretations of EU cooperation forms, fundamental treatises and their future amending strategies. 
3) the global functionalist project, maintaining the idea of the spontaneous formation of the future global reality as an evolutionary process of new legal norms, combining self-regulation and target-oriented initiatives in global governance, which can provide a new international legal order.

Challenge: when searching for actors, there is a danger of splitting them up into smaller and smaller subsets, some of which are not actually capable of producing and maintaining independent narratives. The main subject of debate between three mentioned groups divides them into smaller subgroups according to different visions of key questions - the balance between international and national law, constitutionalisation and fragmentation regimes, universal values and regional peculiarities of their enforcement, a time-table, the comparative forms of integration (transplantation, adaptation or assimilation) of international norms in national jurisdictions.

Facts: at this stage, the parties determine what exactly happened in the past, what matters for them today and what both parties agree with. First of all, one should focus on proven and reliable sources, from which one can highlight important quotes about and significant events in the conflict.

Global constitutionalism, which prevailed at the beginning of the $21^{\text {st }}$ century, is now under question regarding new disintegration impulses disguised in different forms of "anti-globalism".

(1) On the current stage, global (and European) constitutionalism appears to be under attack by fragmentation trends, opposing regional and national interests to the global constitutional agenda. Very often, it was done in the form of right-wing and left-wing legal populism.

(2) The populist reaction does not represent any ideology in the strict meaning of the word but demonstrates the cognitive dissonance in society - the psychological reaction of mass consciousness to the new social reality of a globalised world, the irritation and spontaneous neurotic answers to the current social inconsistencies and unrealisable beliefs.

(3) The main social resource of the populist reaction to international constitutional values is the progressive erosion of the coherence between national and supranational legal regulation. The populist mindset represents its own vision of the constitutional transformation, which is based on an important common source - the growing degradation of trust in global or European constitutional settlements.

(4) Constitutional populism, in spite of the variety of its representations in different regions of the world (ideological, cultural and legal), includes some common traces. Among them, the pessimist view of liberal European values and standards, the nationalist interpretation of state sovereignty, a conservative understanding of legal traditions and identity as opposed to internationally adopted standards of legal regulation.

(5) The conflict between liberal democracy and illiberal populist trends is revealed in the deep mistrust of the independent and neutral character of consti- 
tutional jurisprudence, and an irrational belief in "direct democracy" as a form of protection against the "corrupt" elites.

(6) This trend is realised in a wave of constitutional amendments adopted in recent decades by countries of CEE, the post-Soviet space, and Russia in order to protect national political systems from the external and internal challenges of globalism in its liberal interpretation. This turn from liberal cosmopolitanism or transnational constitutionalism to a regional and national constitutional identity ended the long-term process of constitutional reform and fixed it in a special form of "protective" constitutionalism.

(7) "Protective" constitutionalism is a reaction to the global liberal model in fragmented legal regions or countries, which are not ready to adopt it fully. Constitutionalism is not fully rejected in all its important principles, but substituted on the legislative and cognitive level by restricted norms, institutional frameworks and particular judicial interpretations. As a result, instead of a value-oriented form, we have a state-oriented form of constitutional interpretation. This could even be realised in the form of a constitutional dictatorship, a formally legal transfer of power from a nation to its representative - parliament with one-party domination, the head of state or national leader - who rules on the grounds of meta-constitutional prerogatives given to him by constitutional norms.

It would be a serious mistake to consider all these developments and demands as a nonexistent psychological (or cognitive) reality, a simple manifestation of social apathy, or the "bad will" of the governments and elites under consideration. The populist phenomenon is "real" as an original form of social therapy - the accumulation and legal representation of the disillusionment of the mass consciousness in countries which have been confronted with unpredictable challenges to democracy after a long period of stable development and exaggerated beliefs.

Challenge: to find facts common to both sides. Media files must be checked for authenticity, because there is a large amount of fake information in a conflict situation. The reciprocal pretensions of global constitutionalists and legal populists should be scrutinised in terms of the substance of their substance and practical meaning for policy-makers.

\section{POWER AND TRUTH: INTERESTS, OPINIONS AND REALITY CHECK}

Using CPA, three further parameters should be underlined: background interests and motivation, opinions, and a reality check.

Background interests and motivations: at this stage, the parties determine what underlies the actions of each party described in the facts (stage 3). Here (in contrast to the previous stage) interpretations and hypotheses are welcome. Feelings, desires, fears that each of the parties experienced in the conflict are expressed. This 
helps to create an "empathy list". In order to do so, the parties should consciously try to "step into the shoes of the other party".

(1) Transnational constitutional integration is a complex process, including the whole corpus of existing international treaties and norms; the readiness of all participants to accept and respect them as guiding principles; cooperation between new and traditional actors in their promotion.

(2) This process presumes competitive efforts to stabilize or revise the established rules of the game; practical cooperation in resolving normative conflicts and political disagreements; the variability of adopted strategies of international integration enforcement, and the reactions to them in national legal systems. For example, a group of states can disagree about the binding force of international norms in one area but be in full agreement in the promotion of others. The same is true for an appreciation of the disciplining effect of European norms for countries inside the EU and outside it. The norms could be adopted as formal legal prescriptions or as recommendations and "good practices" of more or less effective global governance regulation.

(3) National political actors can oppose some global projects (for example in ecological protection), but be active in supporting the others (for example in the prevention of terrorism). The cooperation of international and national actors could be more or less important regarding new global challenges such as climate changes, internet regulation or the COVID-19 pandemic crisis. The readiness for dialogue is crucial, especially in upcoming international crises providing unclear consequences for global constitutional values and human rights protection.

(4) The crucial problem cannot reduce the integration agenda to a debate on the question of how large the world of global constitutionalism is, but questions of how large the potential of the world's legal instability and constitutional twilight is, the costs different actors are ready to pay for this, and what should be done on a transnational and national level to stop this move toward international legal disorder.

(5) The adoption of that conclusion forms the ground for a dialogue among all the important international actors on the global crisis-management strategy implying a "rational choice" strategy in terms of the norms, institutions and procedures, capable of minimising if not stopping the spontaneous degradation of constitutional legitimacy and global governance.

Opinions: at this stage, the parties determine where it is possible to build "bridges of understanding". Here it is useful to ask which joint opinions can reduce fears and satisfy as many interests and needs as possible. Any suggestions, even the most daring, are welcome. Brainstorming can identify collective blind spots and misperceptions and is a crucial step in enabling real comprehension between the two parties.

Collective blind spots are issues of the historical narrative of one party, which are not seen or recognised by the other party. The categorisation of an issue as a collective blind spot does not depend on whether the issue is correctly seen from a historical perspective. 
(1) The most prominent criticism of global constitutionalism has been produced by the "critical theory" of law and TWAIL (Third World Approaches to International Law) representatives. ${ }^{104}$ They declared the whole system of international law (in contrast to national ones) as unfair and a historical expression of the dominance of the "Global West" over the "Global East" or over underdeveloped countries in different regions of the World, who historically had no voice in the creation of the modern global legal order but should have in future. In reality, that means the necessity for an alternative, more critical vision of global constitutionalism, its values, principles and priorities (e.g., in the framework of the so-called "post-liberal" concept of the legal order).

(2) The most powerful states are in a position to be even less interested in maintaining international law and global cooperation trying to use their historical advantage to be sovereign and "exceptional" actors in world affairs, demonstrating a commitment to use violence for the protection of their privileged positions.

(3) If this interpretation is true, then the main trend in the nearest future is not a cosmopolitan version of global constitutionalism but the growing fragmentation of international legal order.

Collective misperception are issues that are recognised by the other side, but misperceived. Therefore, in this case, the question of a reliable truth arises. Contrary to "normal" issues of a narrative, these issues are not simply seen differently by each side (every side has its perception of the truth) but due to a lack of knowledge or a lack of interest, they are misperceived.

(1) On the one hand, international law continues to develop, demonstrating the acute necessity for an integrated system of international regulation, and the existing controversies do not devalue its importance because all actors potentially should agree about its norms. On the other hand, the system of international norms and institutions should be perceived as the product of agreement between states about the scope and functions of international norms.

(2) In reality, that means there is growing competition between different regions of the world over the new global order - contrasting visions of this order and their own place in it.

(3) The search for balance in globalisation should be a priority for all the actors involved and realised on the basis of constant verification and independent international monitoring.

Reality check: at this stage, the parties can criticise the opinions proposed at stage (5) in order to bring them closer to reality. The expression of real concerns and a rational approach are welcome.

${ }^{104}$ B.S. Chimni, op. cit., pp. 3-27; Constitutionalism of the Global South...; A. O'Donoghue, R. Houghton, op. cit. 
How far could the process of the constitutional restoration go beyond the established global or European standards? We traced different aspects of this conservative transformation in CEE and the post-Soviet region. This includes re-invented traditionalism and the national legal identity, a reevaluation of representative democracy, and of constitutional jurisprudence and the shifting balance of constitutional design and political regimes, the changing balance of formal and informal practices regarding their impact on the degradation of the general liberal principles of European constitutionalism.

The typology of the constitutional backslide reveals differences in terms of the depth, forms, intensity and potential results for the destiny of the democratic constitutional integrity of European law. Hence the one crucial criteria of the constitutional backslide is not debated - the growing deviation from the principle of pluralism in CEE and the post-Soviet space. The typology of countries under consideration according to these criteria includes three groups: countries where the nucleus of this principle is still alive in spite of some restrictions; countries where it has been substantially deformed by new constitutional and legal changes; and countries where this principle had become more and more nominal.

Classical liberal democracy has no clear remedies for the populist disease just because both of them - democracy and populism - use similar language, terminology and electoral mechanisms. The populist transformation could be fulfilled in a gradual and even invisible manner, i.e. by legal and institutional transformation. That means that we need some complex vision of the causes and effects. Among the recommended prescriptions some are of crucial importance: the fulfillment of European standards, the abolishment of restrictions imposed by governments on NGOs, the development of real political competition and civic organisations, a general constitutional enlightenment, pressure on populist governments from the supra-national institutional level.

For the replacement of this conservative trend, it is important to re-establish the vitality of the eroded liberal identity in its real meaning, to create bridges of mutual understanding between supranational and national elites. This could be done by promoting trust, a new constitutional agenda and political activism capable of overcoming alienation, of filling the vacuum of legitimate legal initiatives in order to maintain the integrity of European constitutional settlement, and confronting the frustration caused by uneven globalisation and its effects. In order to fulfill these targets the systematic elaboration of the new global governance, legal policies, permanent international legal monitoring, and target-oriented constitutional engineering are priorities.

New discoveries: at this stage, the parties sum up. They describe what they have learned in the CPA process which was valuable and useful for them, and plan how to develop further work in this direction. Of course, the development of a common narrative is too far-fetched in the current diversity of global legal 
growth. Instead, the emphasis should be placed on a better understanding of others' perspectives, how the opposing narratives have developed and what makes them convincing for their supporters. The resulting meta-narrative can explain the divergence of contradicting narratives and help to deal constructively with the differences in a forward-looking manner.

(1) Constitutionalisation in itself contains fragmentation regarding such issues as the creation of a system of new diversified actors with different or even contradictory interests - sectorial regulatory regimes, international organisations, NGOs and transnational corporations, academic think tanks and more or less independent groups of political activists acting in parallel with traditional actors - national states and governments.

(2) In spite of the dichotomy of the two trends in international constitutionalism, it is not useful to oppose them as mutually incompatible in a framework of a simple ideological dilemma - a liberal transnational constitution or illiberal fragmented legal regimes.

(3 ) The problem should be formulated in another way: How to find the common areas of interaction, and cooperation in a framework of one and same legal globalisation process?

\section{CONCLUSIONS}

Global (transnational) constitutionalism is not just a solution, but an experimental zone seeking the optimal balance between global, transnational, international and national law-making institutions, and the results are not predetermined by existing legal relations. Global constitutionalism in its current condition is more an ideology and ethical attitude than a stable normative construction. The current crisis (aggravated by the COVID-19 pandemic) has shown the coming of a new phase of the decomposition of international law: the growing competition between global and national elites over the construction of global governance, demonstrating the importance of a consolidated politics of law.

This means that the choice between different models of global governance as an important part of globalisation, should be understood as permanent, regulating international legal development, in order to protect the common ground for a reasonable compromise between regional legal traditions, principles, actors, levels of regulation, institutes and practices. Their interaction, in reality, is not a "zero-sum game". Following this position, the fragmentation of international legal settlement - sectoral, regional and functional - has ideological and pragmatic sides.

From an ideological perspective, fragmentation indeed means the growing limitation of the role and importance of global constitutionalism. Today it is quite reasonable to pose the question: how large is the world of global legal fragmentation 
compared to global legal integration? The very critical position of opponents of global constitutionalism (right- or left-wing), however, is not useful. First, they have not proposed sustainable solutions for global legal integration, reducing the problem to a simplistic opposition, and stimulating regions or states to look for their own home-made strategies of self-protection or adaptation (if not assimilation) to the global order. Second, in spite of rhetoric repudiating "Europe-centrism", the logic, design and terminology of this approach rest on a predominantly "Western-oriented" basis of constitutional organisation on classic democratic models. Third, the final target of global constitutionalism critics is not clear enough to their opponents - do they reject it because of its Western origin, or because it is constitutionalism (i.e., human rights protection), and henceforth its negation does not exclude ipso facto the return to the national autarky and authoritarianism? Such questions are highlighted by the current new wave of constitutional retrenchment in many countries.

From a pragmatic perspective, fragmentation is a correction of global constitutionalism rather than a strict opposition or alternative to it. Not by chance, fragmentation is more visible in those areas of regulation, which are characterised by a lack of trust or a vacuum of responsibility, legitimacy and institutional or functional regulation. Fragmentation in this understanding is a demand for law and justice in areas where the perception of inequality, mistrust, and injustice is more obvious than in other more convenient areas of international affairs. In this role as a "marker" of problematic issues, fragmentation could even have a positive function. It could be regarded as an indicator of problems in the coordination of global, regional and national law; an important part of general research to find the interaction of normative conflict mediation and institutional practices; a form of technical expertise regarding transnational and national dimensions.

If global legal integration and governance are inevitable, the essence of the problem is to find a new and more appropriate balance between integration and fragmentation in cultural, normative and institutional regulation. The solution to these problems would define the possibility of sustainable and solid constitutional guarantees for global and national development in the nearest future. In this understanding regional legislative machinery provides a laboratory for the elaboration and comparison of projects for international institutional reconfiguration in order to avoid global governance dysfunction and the deterioration in "normative disorder"; a place for the presentation and deliberation of competing concepts of future global and regional stability, legitimacy and reform agendas, necessary for approaching this goal. The global rebellion against global constitutionalism in the form of fragmentation, therefore, is not a verdict on the fate of global constitutionalism, but an invitation to renewed dialogue on integration priorities, a dialogue in which the eternal struggle between democracy and authoritarianism will continue on a transnational level. 
The recommended concepts for this dialogue include rival attitudes to global constitutionalism - from positive to negative ones. They can be represented in seven competing strategies for the promotion of dialogue:

1) a more traditional concept of using key norms and institutions of international law to promote it,

2) a gradual reform of international law where global constitutionalism is seen as a product of international law and the associated legal, academic and political agenda,

3) the idea of legal dualism in international and national constitutional law and their "complementarity", which means building modes of relations and interactions between them,

4) the spontaneous transformation (or adaptation) of law under the new conditions of global development through the consistent adoption of new standards and sources of law, the rejection of a number of previous fundamental bases (first of all, the principle of state sovereignty), or a modification of their meaning,

5) a political interpretation of global law and governance: if understood as a process of leveling the conditions for further development, globalisation leads to changes in international relations, increasing the role of binding obligations, constitutionalism and governance, actualising the consideration of law as a "ruler" in general,

6) the principle of the dominance in the process of globalisation of one model of democracy (the "Western" one), often linking its fate with one state (the US), or a group of states (the "West"),

7) the understanding of global constitutionalism as a constant dialogue between its actors, changing the content of a global social contract (the final formula of which, in principle, cannot be found). The agreement of the parties to find a working balance between integration and fragmentation creates, for the participants in the dialogue, a centre of identity which opposes confrontational attitudes to differences and allows the participants to move towards a convergence of positions.

From our point of view, a new formula for global constitutionalism can become the basis for the consensus in the integration vs. fragmentation dispute. We define it from the standpoint of cognitive information theory as a purposeful activity for constructing a new global legal order, where the stages are fixed in the projects, norms and practices which reflect the progress of the whole society towards this goal. ${ }^{105}$

The theory of global constitutionalism in this interpretation is a cognitive framework for a value-neutral study of global legal development that goes beyond its

${ }^{105}$ About cognitive theory of legal constructivism, see more in A.N. Medushevskiy, Kognitivnaya teoriya prava i juridicheskoe konstruirovanie real'nosti, [in:] idem, Politicheskie sochineniya, Moscow-St. Petersburg 2015. 
normative understanding, and include the formation of legal consciousness, a set of psychological, institutional and behavioural attitudes of individuals who are aware of their belonging to the global community.

Overcoming the conflict of philosophical, normative and functional concepts is, therefore, achieved by interpreting them as different (but still complementary) logical (linguistic) expressions of values, norms and attitudes of various levels, ensuring the unity of the system of global legal regulation.

\section{REFERENCES}

\section{Literature}

A Quarter Century of Post-Communism Assessed, eds. M.S. Fish, G. Gill, M. Petrovic, London 2017. Asian Approaches to International Law and the Legacy of Colonialism, eds. J.-H. Paik, S.-W. Lee, K.Y.L. Tan, London 2012.

Atilgan A., Global Constitutionalism: A Socio-Legal Perspective, Heidelberg 2018, DOI: https://doi.org/10.1007/978-3-662-55647-4.

Aydin C., The Politics of Anti-Westernism in Asia: Visions of World Order in Pan-Islamic and Pan-Asian Thought, New York 2007, DOI: https://doi.org/10.7312/aydi13778.

Bartole S., Comparative Constitutional Law - an Indispensable Tool for the Creation of Transnational Law, "European Constitutional Law Review" 2017, vol. 13(4), DOI: https://doi.org/10.1017/ S1574019617000293.

Bellamy R., Political Constitutionalism: A Republican Defense of the Constitutionality of Democracy, Cambridge 2007, DOI: https://doi.org/10.1017/CBO9780511490187.

Benvenisti E., Law of Global Governance, The Hague 2014,

DOI: https://doi.org/10.1163/9789004279124.

Bhandari S., Global Constitutionalism and the Path of International Law, Leiden 2016, DOI: https://doi.org/10.1163/9789004313460.

Bönnemann M., Jung L., Critical Legal Studies and Comparative Constitutional Law, 2005. Brown G.W., The Constitutionalisation of What?, "Global Constitutionalism” 2012, vol. 1(2). Buden B., Zone des Übergangs: Vom Ende des Postkommunismus, Berlin 2009.

Carducci M., Cross-constitutionalism and Sustainable Comparison, [in:] Sociology of Constitutions: A Paradoxical Perspective, eds. A. Febrajo, G. Corsi, London 2016.

Carducci M., Castillo A., Nature as "Grundnorm” of Global Constitutionalism: Contributions from the Global South, "Rivista Brasileira de Direito" 2016, vol. 12(2),

DOI: https://doi.org/10.18256/2238-0604/revistadedireito.v12n2p154-165.

Chicago draft (1948): Committee to Frame a World Constitution Preliminary Draft of a World Constitution, Chicago 1948.

Chimni B.S., Third World Approaches to International Law: A Manifesto, "International Community Law Review" 2008, no. 3, DOI: https://doi.org/10.1163/187197306779173220.

Concepts for International Law: Contributions to Disciplinary Thought, eds. J. D'Aspremont, S. Singh, Cheltenham 2017.

Conflict of Interest in Global, Public and Corporate Governance, eds. A. Peters, L. Handschin, Cambridge 2012.

Constitution-Making in Transnational Legal Order, eds. G. Shaffer, T. Ginsburg, T.C. Holliday, Cambridge 2020. 
Constitutional Assemblies, ed. J. Elster, Cambridge 2018.

Constitutional Courts: Judicial Roles in Global Perspective, eds. D. Kapiszewski, G. Silverstein, R.A. Kagan, Cambridge 2013.

Constitutional Crisis in the European Constitutional Area. Theory, Law and Politics in Hungary, and Romania, ed. A. Von Bogdandi, P. Sonnevend, Oxford 2015.

Constitutional Design for Divided Societies: Integration or Accomodation?, ed. S. Choudhry, New York 2008.

Constitutional Pluralism in the European Union and Beyond, eds. M. Avbelj, J. Komarek, Oxford 2012.

Constitutional Politics in Central and Eastern Europe, eds. A. Fruhstorfer, M. Hein, Berlin 2016.

Constitutionalism of the Global South, ed. D.B. Maldonado, Cambridge 2013.

Constitutions in Authoritarian Regimes, eds. T. Ginsburg, A. Simpser, Cambridge 2014.

De Wet E., The Constitutionalisation of Public International Law, [in:] The Oxford Handbook of Comparative Constitutional Law, eds. M. Rosenfeld, A. Sajó, Oxford 2012.

Delpano R., Fragmentation and Constitutionalisation of International Law: A Theoretical Inquiry, "European Journal of Legal Studies" 2013, vol. 6(1),

DOI: https://doi.org/10.2139/ssrn.2724467.

Diggelmann O., Altwicker T., Is There Something Like a Constitution of International Law? A Critical Analysis of the Debate on World Constitutionalism, "Zeitschrift für ausländisches öffentliches Recht und Völkerrecht" 2008, vol. 68.

Dunoff J.L., Wiener A., Kumm M., Lang A.F., Hard Times: Progress Narratives, Historical Contingency and the Fate of Global Constitutionalism, "Global Constitutionalism" 2015, vol. 4(1), DOI: https://doi.org/10.1017/S204538171400015X.

Eatwell R., Goodwin M., National Populism: The Revolt Against Liberal Democracy, Rindle 2018.

Ekiert G., Three Generations of Research on Post-Communist Politics - a Sketch, "East European Politics and Societies" 2015, vol. 29(2), DOI: https://doi.org/10.1177/0888325414559052.

Fassbender B., The Meaning of International Constitutional Law, [in:] Transnational Constitution Perspectives, ed. N. Tsagourias, Cambridge 2007.

Fassbender B., The United Nations Charter as the Constitution of the International Community, Leiden 2009, DOI: https://doi.org/10.1163/ej.9789004175105.i-216.

Fragmentation vs the Constitutionalisation of International Law: A Practical Inquiry, eds. A. Jakubowski, K. Wierczyńska, London 2016.

Frosini J., Biagi F., Political and Constitutional Transitions in North Africa: Actors and Factors, London 2014, DOI: https://doi.org/10.4324/9781315746142.

Gaps and Overlaps: Navigating through Contested German-Russian-Ukrainian Narratives, Berlin-Moscow 2020.

Global Constitutionalism and Its Challenges to Westphalian Constitutional Law, ed. M. Belov, London 2018.

Global Constitutionalism from European and East Asian Perspectives, eds. T. Suami, M. Kumm, A. Peters, D. Vanoverbeke, Cambridge 2018.

Grimm D., The Achievement of Constitutionalism and Its Prospects in a Changed World, [in:] The Twilight of Constitutionalism?, eds. P. Dobner, M. Loughlin, Oxford 2010,

DOI: https://doi.org/10.1093/acprof:oso/9780199585007.003.0001.

Habermas J., Zur Verfassung Europas, Berlin 2011.

Halmai G., Perspectives on Global Constitutionalism: The Use of Foreign and International Law, The Hague 2014.

Halmai G., The Application of European Constitutional Values in EU Member States: The Case of the Fundamental Law in Hungary, "European Journal of Law Reform" 2018, no. 2-3.

Handbook on Global Constitutionalism, eds. A.F. Lang, A. Wiener, Cambridge 2017. 
Havercroft J., Wiener A., Kumm M., Dunoff J., Editorial. Donald Trump as Global Constitutional Breaching Experiment, "Global Constitutionalism" 2018, vol. 7(1),

DOI: https://doi.org/10.1017/S2045381718000035.

Hawkins B., Holden Ch., A Corporate Veto on Health Policy? Global Constitutionalism and Investor-State Dispute Settlement, "Journal of Health Politics, Policy and Law" 2016, vol. 41(5),

DOI: https://doi.org/10.1215/03616878-3632203.

Heathershow J., Paradox of Power: The Logics of State Weakness in Eurasia, Pittsburgh 2017.

Held D., Cosmopolitanism: Ideas and Realities, Cambridge 2010.

Hirschl R., Towards Juristocracy: The Origin and Consequences of the New Constitutionalism, Cambridge 2004.

Jackson V.C., Constitutional Engagement in a Transnational Era, Oxford 2010.

Jiunn-Rong Y., Wen-Chen Ch., The Emergence of Transnational Constitutionalism: Its Features, Challenges and Solutions, "Penn State International Law Review" 2008, vol. 27(1).

Kirsch N., Beyond Constitutionalism: The Pluralist Structure of Postnational Law, Oxford 2010.

Klabbers J., Peters A., Ulfstein G., The Constitutionalisation of International Law, Oxford 2009, DOI: https://doi.org/10.1093/acprof:0so/9780199543427.001.0001.

Kleinlein T., Constitutionalisation in International Law, "Beiträge zum ausländischen öffentlichen Recht und Völkerrecht” 2012, vol. 231.

Kleinlein T., Peters A., International Constitutional Law, Oxford 2017.

Koskenniemi M., International Law in Europe: Between Tradition and Renewal, "European Journal of International Law" 2005, no. 16, DOI: https://doi.org/10.1093/ejil/chi105.

Kumm M., The Cosmopolitan Turn in Constitutionalism: An Integrated Concept of Public Law, "Indiana Journal of Global Legal Studies" 2013, vol. 20(2),

DOI: https://doi.org/10.2979/indjglolegstu.20.2.605.

Kumm M., Lang A., Tully J., Wiener A., How Large Is the World of Global Constitutionalism?, "Global Constitutionalism" 2014, no. 3, DOI: https://doi.org/10.1017/S204538171400001X.

Law D.S., Versteeg M., The Evolution and Ideology of Global Constitutionalism, "California Law Review” 2011, vol. 99(5), DOI: https://doi.org/10.2139/ssrn.1633108.

Louglin M., What is Constitutionalisation?, [in:] The Twilight of Constitutionalism?, eds. P. Dobner, M. Louglin, Oxford 2010, DOI: https://doi.org/10.1093/acprof:oso/9780199585007.003.0003.

Mair P., Ruling the Void: The Hollowing of Western Democracy, London 2013.

Manela E., The Wilsonian Moment: Self-Determination and the International Origins of Anti-colonial Nationalism, Oxford 2007.

Matczak M., Poland's Constitutional Crisis: Facts and Interpretations, The Foundation for Law, Justice and Society Policy Brief 2018.

Mazover M., No Enchanted Palace: The End of Empire and the Ideological Origins of the United Nations, Princeton-New Jersey 2009, DOI: https://doi.org/10.1515/9781400831661.

Medushevskiy A.N., Constitutional Reform in Russia: Substance, Directions and Implementation, "Forensic Research and Criminology International Journal" 2019, vol. 7(6), DOI: https://doi. org/10.15406/frcij.2019.07.00295.

Medushevskiy A.N., Global Constitutionalism: The Theory of the Global Legal Order or a New Political Ideology?, "Historia Provinciae. The Journal of Regional History" 2020, vol. 4(3), DOI: https://doi.org/10.23859/2587-8344-2020-4-3-8.

Medushevskiy A.N., Kognitivnaya teoriya prava i juridicheskoe konstruirovanie real'nosti, [in:] idem, Politicheskie sochineniya, Moscow-St. Petersburg 2015.

Medushevskiy A.N., Konstitutsionnaya retraditsionalisatsiya $v$ Vostochnoy Evrope i Rossii, "Sravnitel'noye konstitutsionnoye obozreniye" 2018, vol. 134(1).

Medushevskiy A.N., Law and Revolution: The Impact of Soviet Legitimacy on Post-Soviet Constitutional Transformation, "Telos” 2019, vol. 189, DOI: https://doi.org/10.3817/1219189121. 
Medushevskiy A.N., Perechod Rossii k konstitucionnoy dictature: razmyshleniya o znzchenii reformy 2020 goda, "Sravnitel'noe konstitucionnoe obozrenie" 2020, vol. 136(3).

Medushevskiy A.N., Populism in the West and in Russia: A Comparative Perspective of Similarities and Differences, [in:] Populism as a Common Challenge, ed. C. Crawford, Berlin-Moscow 2017.

Medushevskiy A.N., Recht und Gerechtigkeit in den politischen Debatten der postsowjtischen Ara (mit Nachtrag 2017), [in:] Gerechtigkeit in Russland: Sprachen, Konzepte, Praktiken, ed. N. Plotnikov, München 2019.

Medushevskiy A.N., Russian Constitutional Development: Formal and Informal Practices, "BRICS Law Journal” 2019, vol. 6(3), DOI: https://doi.org/10.21684/2412-2343-2019-6-3-100-127.

Medushevskiy A.N., Tendentsii postsovetskich politicheskich rejimov v svete noveisheiy volny konstitucionnych popravok, "Obschestvennye nauki I sovremennost" 2018, no. 2.

Milewicz K., Emerging Patterns of Global Constitutionalisation: Toward a Conceptual Framework, "Indiana Journal of Global Legal Studies" 2009, vol. 16,

DOI: https://doi.org/10.2979/gls.2009.16.2.413.

Milov V., Medushevskiy A., Zaslavskiy I., Constitution and Economy after Putin: A Roadmap for a New Russia, Washington 2018.

Onuma Y., A Transcivilizational Perspective on Global Legal Order in the Twenty-first Century: A Way to Overcome West-centric and Judiciary-centric Deficits in International Legal Thoughts, "International Community Law Review" 2006, vol. 8,

DOI: https://doi.org/10.1163/187197306779173266.

Pederson S., The Guardians: The League of Nations and the Crisis of Empire, Oxford 2015, DOI: https://doi.org/10.1093/acprof:oso/9780199570485.001.0001.

Peters A., Are We Moving Towards Constitutionalisation of the World Community?, [in:] Realizing Utopia: The Future of International Law, ed. A. Cassese, Oxford 2012,

DOI: https://doi.org/10.1093/acprof:oso/9780199691661.003.0010.

Peters A., Compensatory Constitutionalism: The Function and Potential of Fundamental International Norms and Structures, "Leiden Journal of International Law" 2006, vol. 19,

DOI: https://doi.org/10.1017/S0922156506003487.

Peters A., Constitutionalisation, [in:] Concepts for International Law: Contributions to Disciplinary Thought, eds. J. D’Aspremont, S. Singh, Cheltenham 2017.

Peters A., Global Constitutionalism, [in:] Encyclopedia of Political Thought, ed. M. Gibbus, London 2015.

Piccone T., Five Rising Democracies and the Fate of the International Liberal Order, New York 2016.

Populism as a Common Challenge, ed. C. Crawford, Berlin-Moscow 2017.

Power and Legitimacy: Challenges from Russia, eds. P.-A. Bodin, S. Hedlund, E. Namli, LondonNew York 2012.

Preuss U.K., Disconnecting Constitutions from Statehood: Is Global Constitutionalism a Viable Concept?, [in:] The Twilight of Constitutionalism, eds. P. Dobner, M. Loughlin, Oxford 2010, DOI: https://doi.org/10.1093/acprof:oso/9780199585007.003.0002.

Rainers T., Goodwin M., Cutts D., The Future of Europe: Comparing Public and Elite Attitudes, London 2017.

Roux T., The Politico-Legal Dynamics of Judicial Review: A Comparative Analysis, Cambridge 2019, DOI: https://doi.org/10.1017/9781108340977.

Rosenfeld M., Global Constitutionalism: Meaningful or Desirable?, "European Journal of International Law" 2014, vol. 25(1), DOI: https://doi.org/10.1093/ejil/cht083.

Ruling the World? Constitutionalism, International Law, and Global Governance, eds. J.L. Dunoff, J.P. Trachtman, Cambridge 2009.

Russian-Western Blind Spots: From Dialog on Contested Narratives to Improved Understanding, Berlin 2019. 
Sajó A., Uitz R., The Constitution of Freedom: An Introduction to Legal Constitutionalism, Oxford 2017, DOI: https://doi.org/10.1093/oso/9780198732174.001.0001.

Schwöbel Ch.E.J., Global Constitutionalism in International Legal Perspective, Leiden-Boston 2011, DOI: https://doi.org/10.1163/ej.9789004191150.i-205.

Security Narratives in Europe: A Wide Range of Views, ed. W. Zellner, Baden-Baden 2017.

Sihvo O., Global Constitutionalism and the Idea of Progress, "Helsinki Law Review" 2018, vol. 12(1).

Singer A., Ron A., Models of Shareholder Democracy: A Transnational Approach, "Global Constitutionalism" 2018, vol. 7(3), DOI: https://doi.org/10.1017/S2045381718000126.

Somek A., The Cosmopolitan Constitution, Oxford 2014,

DOI: https://doi.org/10.1093/acprof:0so/9780199651535.001.0001.

Sources of Law and of Rights, eds. J. Resnik, A. Liman, Yale 2014.

Sweet A.S., A Cosmopolitan Legal Order: Constitutional Pluralism and Rights Adjudication in Europe, "Global Constitutionalism" 2012, vol. 1,

DOI: https://doi.org/10.1017/S2045381711000062.

Sweet A.S., Constitutionalism, Legal Pluralism, and International Regimes, "Indiana Journal of Global Legal Studies" 2009, vol. 16, DOI: https://doi.org/10.2979/gls.2009.16.2.621.

Teubner G., Constitutional Fragments: Societal Constitutionalism and Globalisation, Oxford 2012, DOI: https://doi.org/10.1093/acprof:0so/9780199644674.001.0001.

The Constitututionalisation of International Law, eds. J. Klabbers, A. Peters, G. Ulfstein, Oxford 2009.

The Oxford Handbook of Caribbean Constitutions, eds. R. Albert, D. O'Brien, S. Wheatle, Oxford 2020.

The Oxford Handbook of Comparative Constitutional Law, eds. M. Rosenfeld, A. Sajó, Oxford 2012. The Oxford Handbook of the Theory of International Law, eds. A. Orford, F. Hoffmann, Oxford 2016. The Twilight of Constitutionalism?, eds. P. Dobner, M. Louglin, Oxford 2010.

Towards World Constitutionalism in the Legal Ordering of the World Community, eds. R.S. Macdonald, D.M. Johnston, The Hague 2005.

Transnational Constitutionalism: International and European Perspectives, ed. N. Tsagourias, Cambridge 2007.

Tsagourias N., Introduction - Constitutionalism: A Theoretical Roadmap, [in:] Transnational Constitutionalism, ed. N. Tsagourias, Cambridge 2009.

Tully J., Dunoff J.L., Lang A.F., Rumm M., Wiener A., Introducing Global Integral Constitutionalism, "Global Constitutionalism" 2016, vol. 5(1), DOI: https://doi.org/10.1017/S2045381715000210.

Von Bogdandi A., Constitutionalism in International Law: Comment on a Proposal from Germany, "Harvard International Law Journal" 2006, vol. 47(1).

Walker N., Post-Constituent Constitutionalism? The Case of the European Union, [in:] The Paradox of Constitutionalism: Power and Constitutional Form, eds. M. Loughlin, N. Walker, Oxford 2008, DOI: https://doi.org/10.1093/acprof:oso/9780199552207.003.0014.

Walter Ch., International Law in a Process of Constitutionalisation, [in:] New Perspectives on the Divide between National and International Law, eds. J. Nijman, A. Nolkaemper, Oxford 2007, DOI: https://doi.org/10.1093/acprof:0so/9780199231942.003.0009.

Westad O.A., The Global Cold War: Third World Interventions and the Making of Our Times, Cambridge 2007.

Wheatley S., The Democratic Legitimacy of International Law, Oxford 2010.

Wiener A., Lang A.F., Tully J., Maduro M.P., Kumm M., Editorial. Global Constitutionalism: Human Rights, Democracy and the Rule of Law, "Global Constitutionalism" 2012, vol. 1,

DOI: https://doi.org/10.1017/S2045381711000098. 


\section{Online sources}

Carrai M.A., Global Constitutionalism and the Challenge of China's Exeptionalism, [in:] Global Constitutionalism without Global Democracy?, eds. C. Corradetti, G. Sartor, "Working Paper LAW" 2016/21, https://cadmus.eui.eu/bitstream/handle/1814/44286/LAW_2016_21.pdf?sequence $=1$ [access: 20.08.2021].

Cubicek P., Regime Transitions and Variation in Post-Communist Europe, 2.04.2020, www.oxfordbibliographies.com/view/document/obo-9780199756223/obo-9780199756223-0115.xml [access: 15.08.2021].

Daly T.G., Democratic Decay in 'Keystone' Democracies: The Real Threat to Global Constitutionalism?, 10.05.2017, www.iconnectblog.com/2017/05/democratic-decay-in-keystone-democracies-the-real-threat-to-global-constitutionalism-i-connect-column [access: 15.08.2021].

Erlanger S., In Eastern Europe, Populism Lives, Widening a Split in the E.U., "The New York Times", 28.11.2017, www.nytimes.com/2017/11/28/world/europe/populism-eastern-europe.html [access: 15.08.2021].

Europe and Globalisation: the Dangers and the Assets 2013, 2.12.2013, www.robert-schuman.eu/ en/european-issues/0296-europe-and-globalisation-dangers-and-assets [access: 15.08.2021].

Global Constitutionalism without Global Democracy?, eds. C. Corradetti, G. Sartor, "Working Paper LAW" 2016/21, https://cadmus.eui.eu/bitstream/handle/1814/44286/LAW_2016_21.pdf?sequence $=1$ [access: 20.08.2021].

Henley J., 30 Years after Communism, Eastern Europe Divided on Democracy's Impact: Pew research reveals very different views on whether countries are better off today, "The Guardian", 15.10.2019, www.theguardian.com/world/2019/oct/15/30-years-after-communism-east-europeans-divided-over-democracys-impact [access: 15.08.2021].

Inmedio's Conflict Perspective Analysis (CPA). Conflict Analysis Tools-Center for Security Studies, 2020, www.css.ethz.ch/content/dam/ethz/special-interest/gess/cis/center-for-securities-studies/ pdfs/Conflict-Analysis-Tools.pdf [access: 15.08.2021].

Kimijima A., Global Constitutionalism and Japan's Constitutional Pacifism, 2011, www.ritsumei. ac.jp/acd/cg/ir/college/bulletin/Vol.23-3/03_Kimijima.pdf [access: 15.08.2021].

Kumar V., Towards a Constitutionalism of the Wretched, 27.07.2017, https://voelkerrechtsblog.org/ towards-a-constitutionalism-of-the-wretched [access: 15.08.2021].

Millard R.J., Adopting Narrative Mediation in Protracted International Conflict: Transcending the Relational and Emotional Hurdles to Resolution in Inter-group Conflicts, 2008, http://hdl.handle. net/1794/8643 [access: 15.08.2021].

Möller A., Pardijs D., The Future Shape of Europe, https:/ecfr.eu/special/the_future_shape_of_europe [access: 15.08.2021].

O’Donoghue A., Houghton R., A Manifesto for Feminist Global Constitutionalist Order, 2018, http:// criticallegalthinking.com/2018/08/01/a-manifesto-for-feminist-global-constitutionalist-order [access: 15.08.2021].

Pop-Eleches G., Tucker B., Europe's Communist Regimes Began to Collapse 30 years ago, but Still Shape Political Views, "Washington Post", 12.11.2019, www.washingtonpost.com/politics/2019/11/12/europes-communist-regimes-began-collapse-years-ago-still-shape-politicalviews [access: 15.08.2021].

Splinter D., Wuestehube L., From Shared Truths to Joint Responsibility. Training Manual for Mediators and Dialog Facilitators, 2017, www.inmedio.de/sites/default/files/training_manual_for_mediators_and_dialogue_facilitators_nepal_withouttrack_changes.pdf [access: 15.08.2021].

Szczypska K., Further Erosion of the Polish Democracy: Providing Feedback for the First EU Rule of Law Report, 5.05.2020, https://en.odfoundation.eu/a/26796,odf-welcomes-persecuted-polish-judges-and-prosecutors-in-brussels [access: 15.08.2021]. 
Pobrane z czasopisma Studia Iuridica Lublinensia http://studiaiuridica.umes.pl

Data: 26/04/2023 15:59:00

Andrei N. Medushevskiy

Techau J., For Predictions on the Future of Europe, 12.01.2016, https://carnegieeurope.eu/strategiceurope/62445 [access: 15.08.2021].

Xavier S., False Universalism of Global Governance Theories: Global Constitutionalism, Global Administrative Law, International Criminal Institutions and the Global South, PhD Dissertation, 2015, http://digitalcommons.osgoode.yorku.ca/phd/20 [access: 15.08.2021].

\begin{abstract}
ABSTRAKT
Globalizacja dokonała głębokich przekształceń w zakresie prawa międzynarodowego, spraw politycznych i sprawowania władzy, pociągając za sobą wzajemnie sprzeczne konsekwencje. Pobudziła kosmopolityczny projekt globalnego konstytucjonalizmu, integracji ponadnarodowej i ujednolicenia standardów demokratycznych. Doprowadziła jednak również do fragmentacji sfery spraw międzynarodowych, osłabienia demokracji konstytucyjnej oraz poczucia rosnącego deficytu demokracji na szczeblu krajowym i międzynarodowym. Podejmując próbę zrównoważenia wpływu tych dwóch przeciwstawnych tendencji, autor analizuje pozytywne i negatywne skutki globalizacji dla rozwoju ustroju konstytucyjnego w odniesieniu do takich kwestii, jak: transnarodowa konstytucjonalizacja, demokracja i suwerenność narodowa, zmieniające się miejsce wielowarstwowego konstytucjonalizmu, międzynarodowy podział władz oraz system globalnego sprawowania rządów przy ustalaniu ponadnarodowej legitymacji demokratycznej. Z tego punktu widzenia powrót populizmu w Europie Środkowej i Wschodniej wydaje się niebezpieczny i nieprzewidywalny, ale jest to systemowa i potencjalnie przewidywalna reakcja globalnych regionów na nierówności w integracji, brak legitymacji demokratycznej, a także nowa odpowiedź na zniekształcenia i dysfunkcje sprawowania władzy na świecie. Właściwej odpowiedzi na te wyzwania można upatrywać w nowej koncepcji integracji konstytucyjnej opartej na trwającym dialogu między ponadnarodowymi i krajowymi podmiotami globalizacji prawnej. Dialog ten jest możliwy dzięki wykorzystaniu strategii mediacji w konfliktach, opracowanej przez międzynarodowych ekspertów, zwłaszcza do rozstrzygania skomplikowanych i długotrwałych konfliktów, których nie daje się praktycznie rozwiązać w perspektywie krótkoi średnioterminowej.
\end{abstract}

Słowa kluczowe: konstytucjonalizm globalny; konstytucjonalizacja; fragmentacja; suwerenność; legitymacja; strategia mediacji w konfliktach 